Nat. Hazards Earth Syst. Sci., 18, 2471-2488, 2018

https://doi.org/10.5194/nhess-18-2471-2018

(C) Author(s) 2018. This work is distributed under

the Creative Commons Attribution 4.0 License.

\title{
Review article: Climate change impacts on dam safety
}

\author{
Javier Fluixá-Sanmartín ${ }^{1}$, Luis Altarejos-García ${ }^{2}$, Adrián Morales-Torres ${ }^{3}$, and Ignacio Escuder-Bueno ${ }^{4}$ \\ ${ }^{1}$ Centre de Recherche sur l'Environnement Alpin (CREALP), Sion, 1951, Switzerland \\ ${ }^{2}$ Department of Civil Engineering, Universidad Politécnica de Cartagena (UPCT), Cartagena, 30202, Spain \\ ${ }_{3}^{3}$ Presas Risk Analysis, Valencia, 46023, Spain \\ ${ }^{4}$ Department of Hydraulic Engineering and Environment, Universitat Politècnica de València (UPV), Valencia, 46022, Spain
}

Correspondence: Javier Fluixá-Sanmartín (javier.fluixa@crealp.vs.ch)

Received: 13 May 2018 - Discussion started: 16 May 2018

Revised: 13 August 2018 - Accepted: 27 August 2018 - Published: 17 September 2018

\begin{abstract}
Dams as well as protective dikes and levees are critical infrastructures whose associated risk must be properly managed in a continuous and updated process. Usually, dam safety management has been carried out assuming stationary climatic and non-climatic conditions. However, the projected alterations due to climate change are likely to affect different factors driving dam risk. Although some reference institutions develop guidance for including climate change in their decision support strategies, related information is still vast and scattered and its application to specific analyses such as dam safety assessments remains a challenge.

This article presents a comprehensive and multidisciplinary review of the impacts of climate change that could affect dam safety. The global effect can be assessed through the integration of the various projected effects acting on each aspect of the risk, from the input hydrology to the calculation of the consequences of the flood wave on population and assets at risk. This will provide useful information for dam owners and dam safety practitioners in their decisionmaking process.
\end{abstract}

\section{Introduction}

Large dams as well as protective dikes and levees are critical infrastructures whose failure has high economic and social consequences. Although usually very low, these infrastructures have an associated risk that must be properly managed in a continuous and updated process. In the dam safety context, risk can be estimated by the combined impact of the scenario, probability of occurrence, and associated consequences (ICOLD, 2003). Risk analysis is a use- ful methodology that encompasses traditional and state-ofthe-art approaches to manage dam safety in an accountable and comprehensive way (Bowles, 2000; Serrano-Lombillo et al., 2013). The development and application of risk assessment techniques worldwide in the dam industry (ANCOLD, 2003; ICOLD, 2005; SPANCOLD, 2012; USACE, 2011b) has helped inform safety governance and support decisionmaking in the adoption of structural and non-structural risk reduction measures.

Most risk assessments in the past assumed a stationary condition in the variability in climate phenomena, including the frequency and magnitude of extreme events (National Research Council, 2009). However, changes in climate factors such as variations in extreme temperatures or frequency of heavy precipitation events (CH2014-Impacts, 2014; IPCC, 2012b; Walsh et al., 2014) are likely to affect the different factors driving dam risks (Bowles et al., 2013a; USBR, 2014). The assumptions of stationary climatic baselines are no longer appropriate for long-term dam safety management (USACE, 2016). An update of risk components (loads, system response, and consequences) to take into account the new climate change scenarios becomes imperative for adaptation and decision-making support under a more resilient approach.

In this context, some reference institutions (USACE, 2014; USBR, 2014, 2016) are actively developing and implementing guidance for including climate change in their decision support strategies (U.S. Government Accountability Office, 2013). In other cases, efforts have been made in the evaluation of climate change impacts on dam safety surveillance but further research is subjected to new findings and advances in the knowledge (OFEV, 2014). 
However, climate-change-related information is vast and scattered, and its application to specific analyses such as dam safety assessments remains a challenge for the dam engineering community. Although a considerable amount of research has been carried out so far, its application to current dam safety practice is still uncertain (Bahls and Holman, 2014) and must be based on national and supranational overall adaptation plans (Commonwealth of Australia, 2015; European Commission, 2013; OECC, 2008). Moreover, the impacts of climate change effects on dam safety are usually analysed separately and aim at specific aspects. Most studies tend to focus only on the impact of climate change on the hydrological loads (Bahls and Holman, 2014; Chernet et al., 2014; Novembre et al., 2015), relegating or ignoring other aspects. Other studies with a wider scope only reach qualitative assessments (Atkins, 2013), limiting their applicability to screening analyses.

The global effect of climate change on dam risk must be assessed through the integration of the various projected effects acting on each aspect, taking into account their interdependencies, rather than by a simple accumulation of separate impacts. It is thus valuable to adopt a comprehensive approach to address climate change influence on dam safety management. In this context, dam risk models represent a useful basis on which such assessments can be structured.

In this work the authors seek a multidisciplinary and structured review of the most relevant impacts of climate change on the different dam safety components, from the input hydrology to the calculation of the downstream consequences of the inundation on population and assets at risk. In order to decompose such impacts on the different risk aspects, a risk analysis approach has been adopted. Moreover, practical techniques for their direct application are presented to provide useful information for dam owners and dam safety practitioners in their decision-making process.

\section{Risk analysis approach for structuring climate change impacts}

The effects of climate change are expected on a variety of factors affecting the dams, from the incoming floods to the definition of downstream consequences. Thus, in order to analyse the impacts of climate change on the global safety of a dam, it is necessary to decompose them into the different aspects that integrate the dam risk. Some techniques help address such analyses in a comprehensive way and structure the way in which the risk assessment is envisaged.

In particular, risk analysis is a useful methodology to manage dam safety in an accountable and comprehensive way (Bowles et al., 2013b). Risk can be defined as the combination of three concepts: what can happen (infrastructure failure), how likely it is to happen (failure probability), and what the consequences are (failure consequences) (Kaplan, 1997). Merz et al. (2010) propose a non-stationary definition of flood risk that includes damage and probability of occurrence. Based on these definitions, risk can be quantified with the equation set by Kaplan and Garrick (1981) and used extensively across different sectors in the industry (Altarejos-García et al., 2012; Aven, 2012; Serrano-Lombillo et al., 2011):

risk $=$

$\int P($ loads $) \cdot P($ response $\mid$ loads $) \cdot C($ loads, response $)$,

where the integral is defined over all the events under study, $P$ (loads) is the probability of the different load events, $P$ (response|loads; ) is the conditional probability of the structural response for each load event, and $C$ (loads,response) is the consequences of the system response for each load event.

In this context, risk models are the basic tool used for the quantitative assessment of risk, integrating and connecting most variables concerning dam safety (Ardiles et al., 2011; Bowles et al., 2013a; Serrano-Lombillo et al., 2012). These models can be structured using influence diagrams such as the one presented in Fig. 1 (SPANCOLD, 2012). Each node represents a variable related to each term of risk as defined in Eq. (1).

- Loads of the system. This term corresponds to the loads to which the dam will be subjected and focuses on the upstream components of the dam. In particular, incoming floods are envisaged as the main hydrological load, and the rest of the component defines how the damreservoir system responds when confronted by such hydrological events.

- System response (or failure probability). This contains the information of the failure modes and the definition of the conditional probability of failure.

- Consequences (economic, loss of life or any other). This component includes an estimation of the consequences downstream of the dam for all the significant failure modes, including the dam break modelling.

In this work, the risk modelling approach shown in Fig. 1 has been chosen to structure and organize the assessment of all the potential impacts by disaggregating them on the different components of risk. The advantage of using this approach is threefold:

- The analysis is performed in a comprehensive way in which the total risk and the climate change impacts are evaluated jointly, taking into account their interdependencies.

- All the risk components are evaluated, which avoids neglecting certain factors affecting the global safety. 


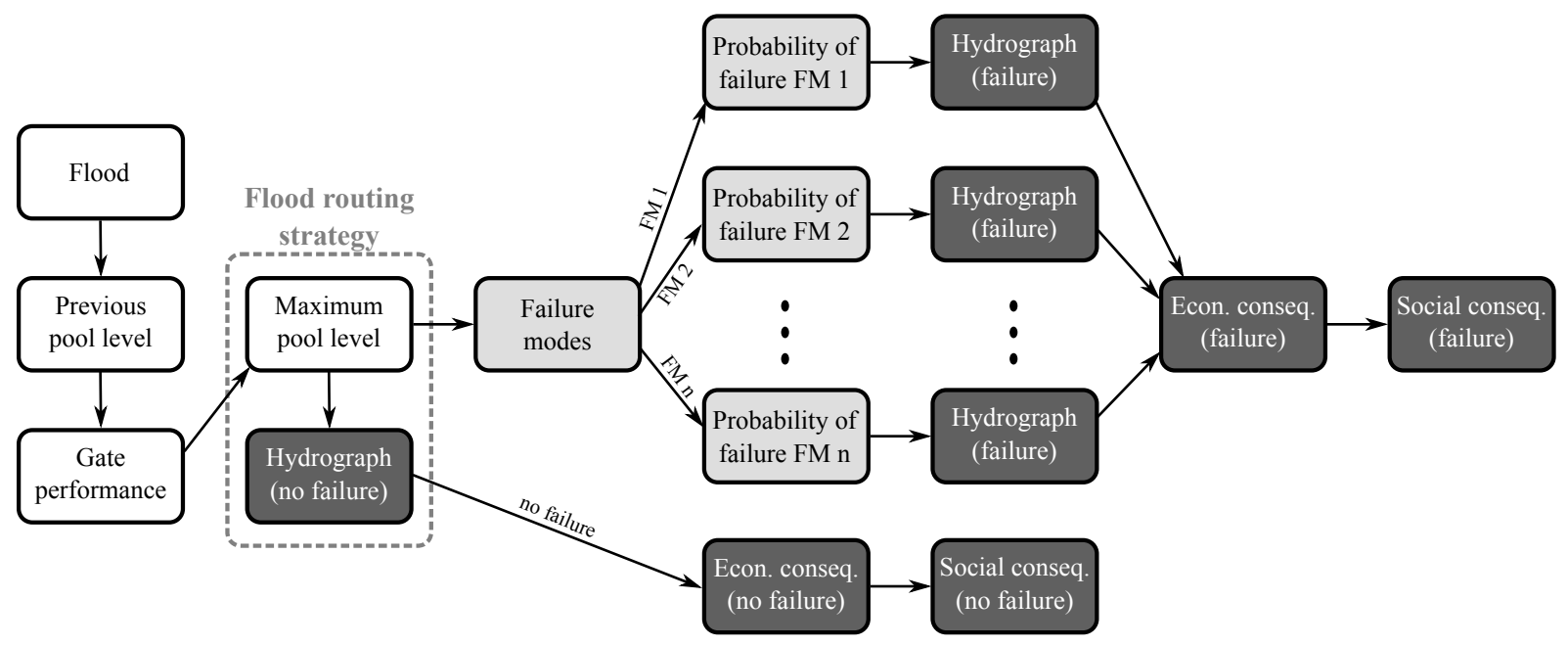

Legend for nodes:

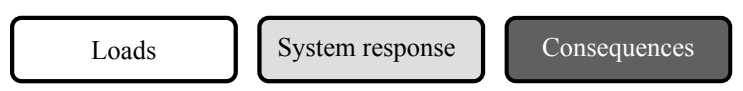

Figure 1. Standard risk model diagram for the hydrologic scenario, divided into loads, system response, and consequence nodes (adapted from SPANCOLD, 2012).

- It is also possible to determine the contribution of each dam safety component to the overall risk impact, thus highlighting which is more susceptible to climate change or has more influence in the final risk level.

\section{Climate change impacts on dam risk components}

What follows is a review of the main climate change impacts on the dam risk components as presented in Sect. 2. The overall effect of climate change on risk can be assessed based on how these components are susceptible to change.

The present review focuses on the impacts of climate change on dam's safety under a hydrological scenario, which means that floods are the main load component to which the dam-reservoir system is subjected.

It is worth mentioning that risk impacts of climate change are conditioned by climatic but also by non-climatic drivers (IPCC, 2014) such as population increase, economic development, or water management adaptation. In certain cases, these non-climatic drivers may have a significant influence in the dam risk calculation and have been considered in the research.

Moreover, climate change can impact both normal components (such as the population exposure downstream of the dam) and extreme components (such as the flood events) of risk, which can be captured by using the proposed risk analysis approach.

\subsection{Loads of the system}

\subsubsection{Flood}

In the hydrological scenario, floods are the initiating event (node) that create the loads to which the dam is subjected and will be referred to here as the upstream flow into the reservoir. The probabilities of the emerging branches are defined by the frequency occurrence linked to the inflow hydrographs (Fig. 2a), introducing the temporal component to the risk calculation [consequences/year]. These are associated with a given return period $(T)$ or its equivalent annual exceedance probability. Different analyses can be performed to estimate the occurrence probability of these events using deterministic, parametric, probabilistic, and stochastic methods (World Meteorological Organization, 2008). Some of them seek relating the magnitude of one or more hydrological variables with $T$. A widely used approach to characterize this relation is to perform frequency analyses of the maximum values of peak discharge $\left(Q_{\mathrm{P}}\right)$ and/or volume $(V)$ (Fig. 2b): while univariate analyses focus on the individual influence of each factor, multivariate analyses are used to obtain their joint distribution in order to know the probability of occurrence of a given inflow hydrograph (Requena et al., 2013; Serinaldi and Grimaldi, 2007; Zhang and Singh, 2006). The main component of dam safety affected by climate change is the hydrology of river basins defined by the incoming floods. Heavy precipitation has an important influence, but floods are also affected by other factors including snow cover and snowmelt (Arheimer and Lindström, 2015; 
(a)

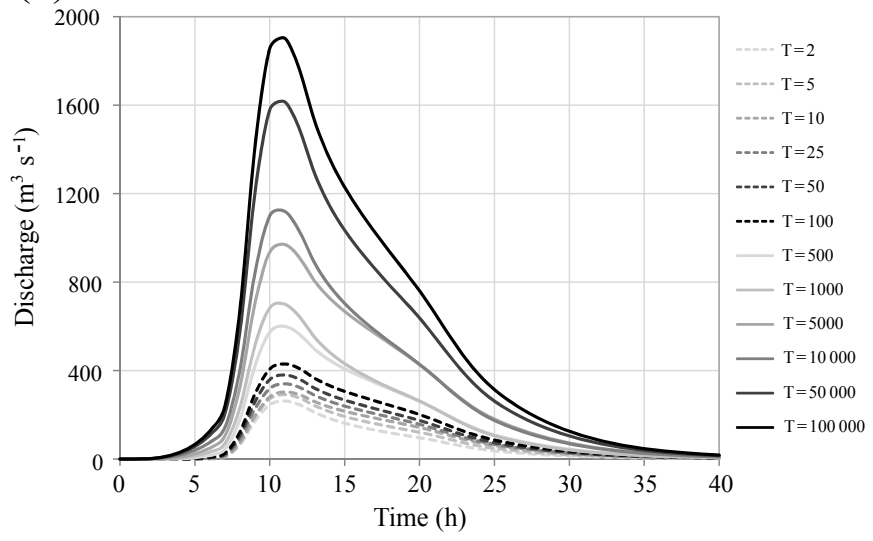

(b)

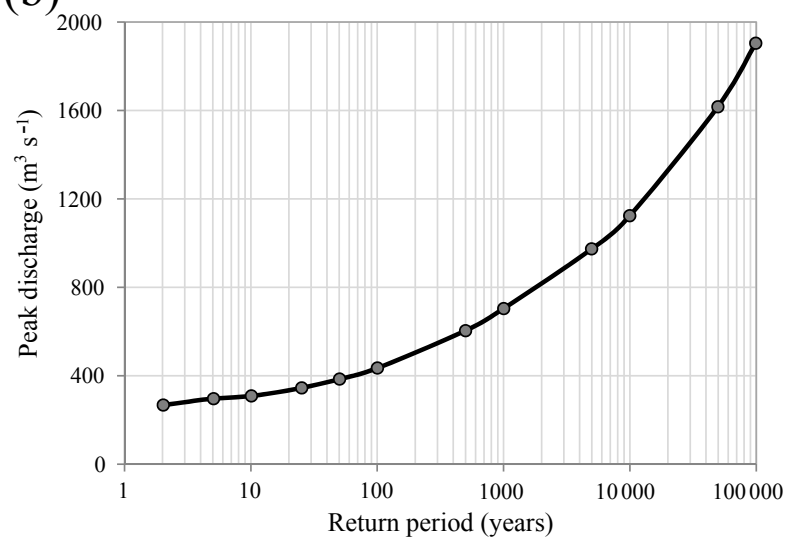

Figure 2. (a) Example of upstream hydrographs as used in the flood routing computation. (b) Resulting flood frequency characterization of the maximum values of peak discharge $\left(Q_{\mathrm{P}}\right)$, used in the flood node.

Fassnacht and Records, 2015), vegetation, or soil moisture (Mostbauer et al., 2017). Changes already identified in these factors are likely to modify the characteristics of floods, namely their magnitude and/or frequency (IPCC, 2014).

The assessment of the correspondence between changes in climate factors and flood occurrence remains, however, complex. Although there are abundant studies on the changes and trends in rivers over the past years (Hannaford and Marsh, 2008; Petrow and Merz, 2009; Villarini et al., 2009), there is still a lack of evidence regarding patterns in the magnitude and/or frequency of floods on a global scale (IPCC, 2012b). Nevertheless, physical reasoning suggests that projected variations in heavy rainfall and other factors in some catchments or regions would contribute to variations in local floods (Bates et al., 2008; Kundzewicz et al., 2007). Existing analyses of flood changes at the basin scale (Prudhomme and Davies, 2009; Raff et al., 2009; Taye et al., 2011) justify the need for a re-evaluation of flood frequency and magnitude impacting dam safety. To take into consideration the non-stationarity hypothesis in flood frequency analysis, some works apply methods to account for the effects of climate change in flow regimes (Gilroy and McCuen, 2012; López and Francés, 2013).

Direct analyses of the expected changes in flood frequency and/or magnitude can be applied using existing studies of the matter in the study region. For instance, the works of Dankers and Feyen (2008), Hirabayashi et al. (2013), or Wobus et al. (2017) present the expected variations in characteristic floods in magnitude or frequency at large scales (Fig. 3). These variations can then be applied to the concerned floods of the basin by a simple extrapolation of the hydrographs based on the ratio between their peaks.

More specific analyses require one to rely on local effects on floods (at a catchment-wide scale) rather than apply regional- or continental-scale findings. When no detailed information is available at the catchment level, site-specific analyses are required. Most studies use adapted global and regional climate models (GCMs and RCMs) coupled with hydrological and land surface models to assess how floods are expected to change at the watershed level (Chernet et al., 2014; Duan et al., 2017; Khazaei et al., 2012). Climate models can be applied to present or historical climatic variables (mainly precipitation and temperature) in order to obtain projections of future climate series (preferably at daily or subdaily time steps). These new series are then introduced as inputs to the hydrological model. The resulting flows are then statistically analysed (the longer the simulation period, the more accuracy) to derive the flood frequency statistics.

In most cases climate change projections from GCMs cannot be directly used because their spatial resolution is too coarse for modelling the hydrological processes at the required regional or even local scale and thus must be downscaled and eventually bias-corrected. A synthetic diagram of a common methodology for the frequency analysis of floods as used in Chernet et al. (2014), Duan et al. (2017), Kay et al. (2006), Raff et al. (2009), or Shamir et al. (2015) is presented in Fig. 4. The possible downscaling techniques available can be divided into dynamical downscaling based on RCMs, statistical downscaling, and a combination of both. Some techniques may be more appropriate than others to simulate precipitation and other extremes (Sarr et al., 2015; Sunyer et al., 2012).

Modelling extreme events remains a challenge, and still more research is needed for analysing and refining the performance of downscaling techniques. Most downscaling techniques are designed to reproduce the mean of the climate signal, which could lead to underestimation of the magnitude of the triggering precipitations, although some studies can be found that handle the projection of extreme events (Arnbjerg-Nielsen et al., 2013; Dobler et al., 2013; PereiraCardenal et al., 2014; Sarr et al., 2015; Willems, 2012). Other limitations have been identified, for instance, in regions with 

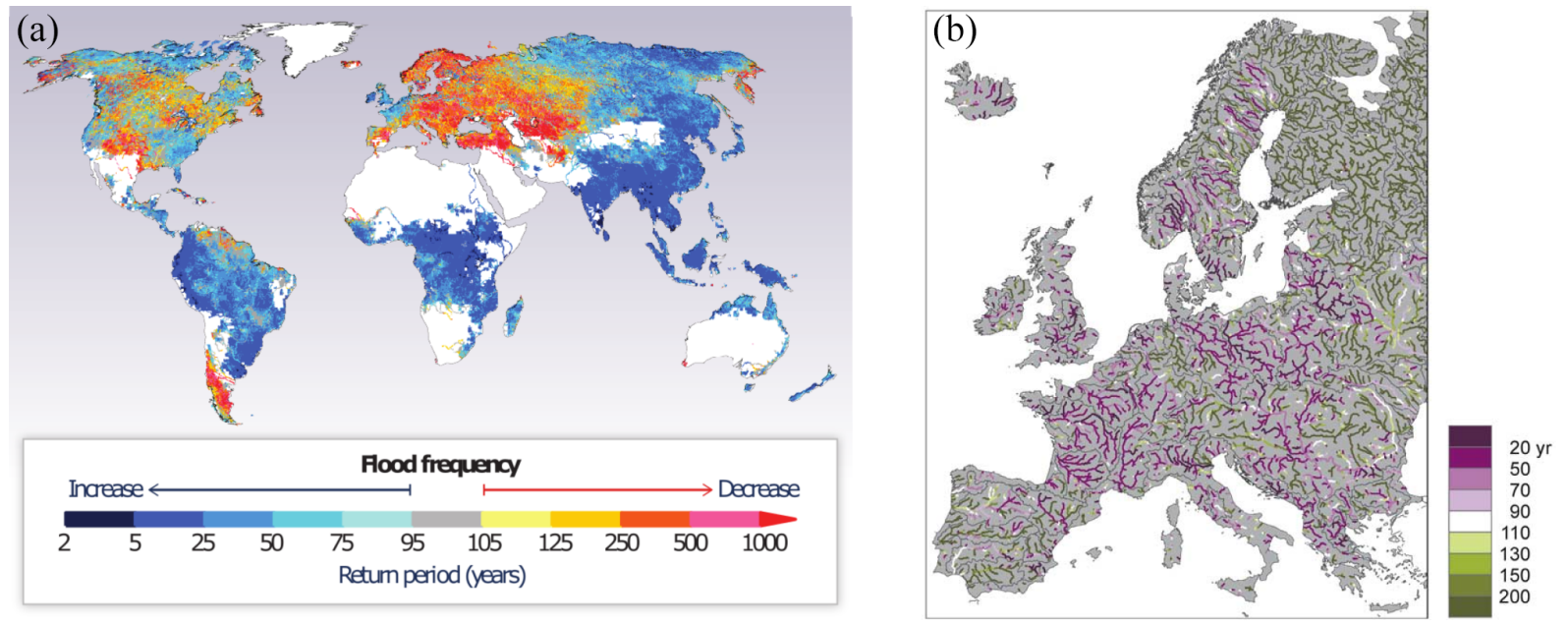

Figure 3. (a) Multi-model median return period (years) in the 2080s for the 20th century 100-year flood based on one hydrological model driven by 11 GCMs under RCP8.5 (from Hirabayashi et al., 2013). (b) Change in recurrence of a 100-year flood in Europe in the H12A2 scenario run using a Gumbel distribution (from Dankers and Feyen, 2008).

a complex topography; in such cases, statistical downscaling performs more adequately to generate higher-resolution climate change scenarios (Dobler et al., 2013). Moreover, more attention must be paid to test the influence of nonstationarity in extreme events for flood frequency estimation (Kjeldsen et al., 2014), which is a major uncertainty when applying statistical downscaling techniques (Dixon et al., 2016; Lanzante et al., 2018). Traditionally, frequency analyses are based on the assumption of independency and stationarity of extreme events, which can eventually lead to a miscalculation of the resulting flood quantiles (Šraj et al., 2016; Zhang et al., 2015). Alternative approaches that incorporate the effects of non-independence and non-stationarity (for instance, by using time-varying distribution parameters; Khaliq et al., 2006) can improve the accuracy of the processes. Other attempts seek to reduce these uncertainties related to the statistical downscaling, making use of stochastic weather generators (Wilks, 2010), which produce synthetic time series of weather data for a location based on the statistical characteristics of observed weather at that location.

Additionally, impact assessment can benefit from deeper investigations. For instance, uncertainties are inherent in both climate and hydrological projections and should be incorporated to the analyses. These may come from the consideration of several climate models or scenarios (Knutti et al., 2010), but also from the techniques used to obtain a specific projection (e.g. the downscaling method chosen), the hydrological model structure, or the parameter identifiability (Chaney et al., 2015). In some cases it can be useful to apply several downscaling methods and compare the results (Willems, 2013).

Studies might also consider the effects of time-varying watershed model parameters in extreme flood climate change studies. For instance, glacier retreat is expected to intensify, leading to an alteration of the flow regimes, especially in high mountain regions (Huss et al., 2010). Also, potential evapotranspiration is very likely to increase in a warmer climate, therefore changing the soil conditions when flood events happen. These conditions can in turn influence the generation and propagation of flood hydrographs. Moreover, using flood information separately by season can be useful in basins or environments strongly influenced by snow precipitation and storage, where changes in melting of winter snow due to a global warming may play a significant role in peak river runoff (Lawrence et al., 2014).

\subsubsection{Reservoir water levels}

The distribution of the water storage in the reservoir, and thus of the pool levels, determines the loads to which the dam is subjected at the moment of arrival of a flood. A dam with a reservoir that is frequently full will be subjected to higher hydrostatic loads than one with larger fluctuations that is less likely to be full. This is captured in the curves representing the relation between water pool level and probability of exceedance for two different cases (Fig. 5): the continuous curve represents the case of Reservoir A, which is almost full (level above $540 \mathrm{~m}$ a.s.l.) almost $80 \%$ of the time, while the discontinuous cure represents Reservoir B, which is half empty more than $70 \%$ of the time. Such distributions depend basically on the inflows, the demands, the reservoir management rules, and the water losses (evaporation, infiltration, etc.) and can be obtained either by using the register of historic pool levels or through the simulation of the system of water resources management.

Under climate change, surface water availability is expected to fluctuate mainly due to increased precipitation variability (IPCC, 2014) and potential evapotranspiration 


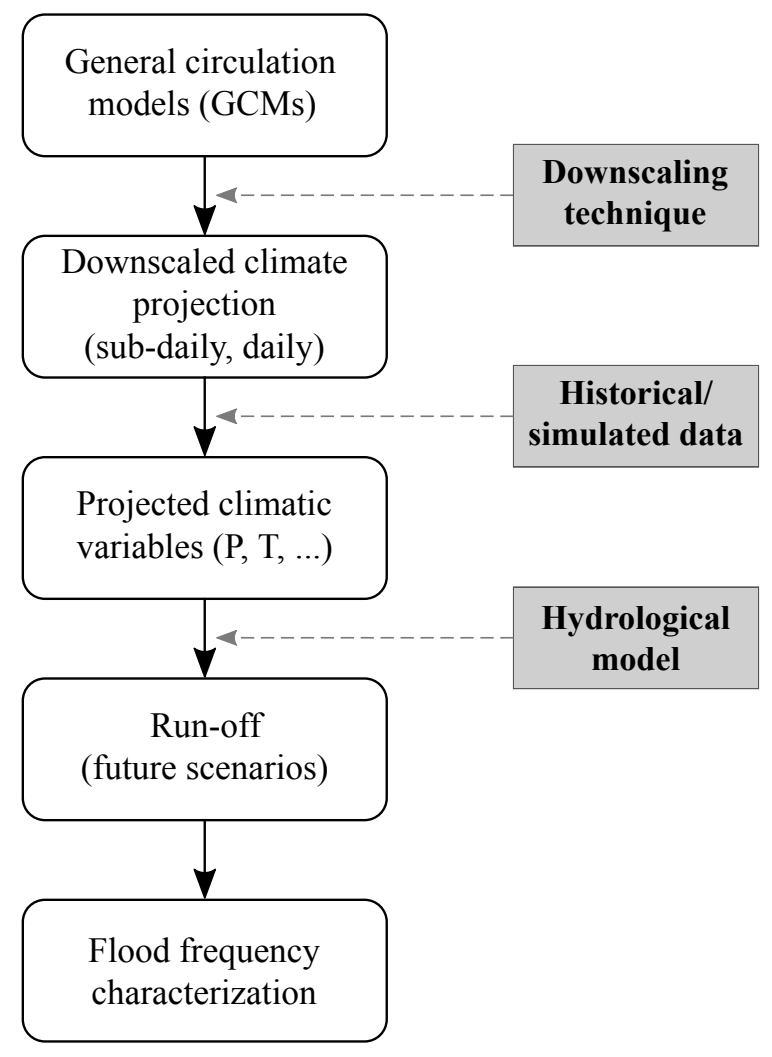

Figure 4. Example methodology for the frequency analysis of floods under climate scenarios based on downscaled projections.

associated with global warming (Kingston et al., 2009; Seneviratne et al., 2010). However, other factors such as decreased snow and ice storage (Huss, 2011) may have a significant influence. Changes in agricultural land uses, which accounts for about $90 \%$ of global water consumption, are also expected to impact freshwater systems, affecting both the hydrological processes given in the catchment and the water irrigation needs. Moreover, water demand and allocation are strongly driven by demographic, socioeconomic, and technological changes, such as population growth, changes in land use, or the adaptation of the reservoirs' exploitation strategies.

The combination of these factors is likely to alter the balance between water availability and supply and thus will have a direct impact on the water levels in the reservoir. This impact does not only refer to the quantity but also to the temporal distribution of the water stored, which has a key impact in the dam safety as stated before.

When assessing the effects of climate change on the distribution of the reservoir water levels, analyses must rely on the simulation of the system of water resource management. This allows the reproduction of the water balance in the reservoir under specific management rules and for future conditions. First, the inflows are assessed, preferably using long updated climatic series obtained from specific climate models as in-

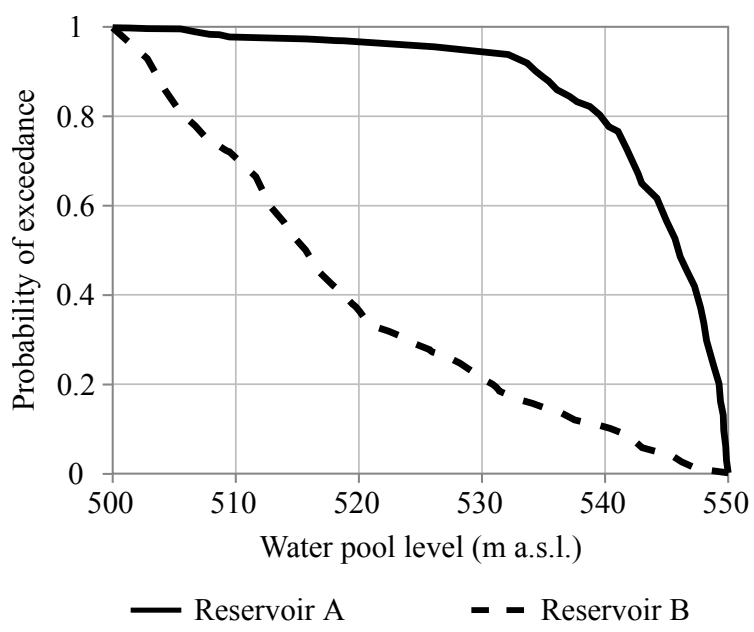

Figure 5. Examples of the relation between water pool level and probability of exceedance.

puts to a hydrological model. This in turn models the basin behaviour and provides the inflow discharges at the reservoir. These results can then be coupled with the modelling of the system of water resources that computes the allocation and use of the water based on the reservoir's exploitation rules. For complex systems (e.g. the joint operation of several reservoirs), this can be performed using simulation tools such as HEC-ResSim (Klipsch and Hurst, 2007) or AquaToolDMA (Andreu et al., 1996). The results of such models are the projected water storage evolution that can be transformed in reservoir level series from which the previous pool levels curve can be obtained.

Here too the uncertainties inherent in climate and hydrological projections should be incorporated in the analysis. In this case, the conditions assumed for the water resources' exploitation modelling are also subjected to an uncertainty analysis. Additionally, non-climatic drivers affecting any component of the water balance computation (e.g. changes in land use, adaptation of reservoir's exploitation rules) can be significant and thus should be included in the analysis. However, the amount of information and work required, and the multiple determining factors involved, can make this procedure impracticable and must be envisaged only when the complexity of the system and the availability of data and time allow it.

\subsubsection{Gate performance}

Spillways and outlet works play a fundamental role in dam safety. They must ensure a certain discharge when required by the arrival of a certain flood. It is therefore important to assess any potential effect that could boost the failure of their regulating gates. Among the different causes that can induce a gate failure, the following are worth mentioning (Lewin et al., 2003; SPANCOLD, 2012): human failure, lack of access to the manoeuvre chamber, mechanical failure of the 
Table 1. Standard individual reliabilities of the spillway gates.

\begin{tabular}{lr}
\hline Case & Reliability \\
\hline Non-gated & $100 \%$ \\
New / very well maintained & $95 \%$ \\
Well maintained, some minor problems & $85 \%$ \\
Some problems & $75 \%$ \\
Unreliable & $50 \%$ \\
Unreliable & $0 \%$ \\
\hline
\end{tabular}

gate or of the civil works, electrical failure, blockage of the outlet works or spillway, or failure in the software controlling the gate or the valve.

An important aspect for the gates' proper function is their good condition. Severe deficiencies and deterioration could render the outlet works or spillway useless. More intense rainfalls may lead to more soil erosion (Yang et al., 2003), which can be further fostered by changes in land use. Then, an increase in the sediment content of water can worsen the abrasion and erosion processes on the gates, their mechanical equipment, or the spillways (British Columbia et al., 1998), thus compromising their reliability. In addition, if the water carries more and bigger suspended material (including trees, branches, or debris) this could lead to a blockage of one of the gates, thus reducing the discharge capacity (Paxson et al., 2016). Changes in temperature can also affect the correct manoeuvring of the gates. Hotter or colder conditions, or even greater fluctuations in temperature, can expose gates' mechanisms to additional stresses and/or deformations. This could eventually lead to blockages or malfunctioning of the gates.

The assessment of such impacts on the gates' reliability can be performed using the qualitative description of the gate system's condition. These descriptors are based on standard cases used in dam risk analysis and are shown in Table 1, without it being necessary to resort to detailed studies such as fault trees (Escuder-Bueno and González-Pérez, 2014). The quantitative individual reliability of the gate (i.e. the probability that it behaves properly) is related to a qualitative description of the condition of the gate system. By estimating the importance of new climatic conditions and stressors such as those mentioned above, one can assess if the gate's state must be updated and thus modify its reliability accordingly.

For more detailed studies, a deeper analysis of the causes and of the assigned failure probabilities is required. The use of fault trees (not to be mistaken for event trees) is a good option to study them in detail (SPANCOLD, 2012; Stamatelatos et al., 2002). Such tools include all the possible manners in which a gate can fail and disaggregate all the failure probabilities, however small they are (Lewin et al., 2003).

\subsubsection{Flood routing strategy}

This component defines how the dam-reservoir system should respond when confronted by a hydrological event. A correct operation of the reservoir allows adequate safety levels to be maintained. Such safety levels will also depend on the characteristics of the dam-reservoir system: for some reservoirs the sufficient storage capacity to absorb the inflowing volumes will be determinant, while for others an adequate capacity of releasing peak inflows may be the dominant factor.

Indeed, the routing of the incoming floods reduces the loads to which the dam is subjected. The capability of the dam to perform such routing depends on the state of the outlet works needed to release the discharges as well as on adapted gate operation rules. Potential effects of climate change on these aspects should be checked.

The operation procedures of the regulated gates establish the desired outflow discharge at any given moment. These procedures will usually be defined depending on a variety of factors, such as the reservoir's water level and its evolution, the inflow discharge, time, etc. Under changes in climate conditions, flood routing strategies are likely to adapt. For instance, the increase in transported sediments driven by soil erosion will accelerate their accumulation within the reservoir, thus impairing the reservoir operation and decreasing its routing capacity and even posing safety hazards to the dam infrastructure (Kondolf et al., 2014; USBR, 2006). Also, changes in heavy rainfall patterns may induce variations in the flood hydrographs' concentration time, thus reducing the response capacity. This may compel the re-evaluation of operation criteria, especially when relying on methods based on the remaining routing volume such as the volumetric evaluation method (Girón, 1988).

Changes in the reservoir's operation criteria should be analysed under deep analyses that rely on the possible evolution of these criteria attending to climatic and non-climatic drivers. When comparing present and future risk, it is recommended to adapt current operation rules. First, the drivers affecting the definition of the operation rules must be identified. Then, under the consideration of the climate change scenarios adopted, the analysis of the influence on such drivers is performed. Finally, the operation criteria are re-evaluated accordingly. Given the important uncertainty involved in the process, this must be treated carefully to avoid inefficiencies in the analyses; only the most relevant and clear aspects of the problem should be addressed.

\subsection{System response}

\subsubsection{Failure modes}

Failure modes represent the possible ways in which the dam may fail: overtopping, pipping, sliding, etc. Their definition is a key process in risk analysis (FEMA, 2015) since 
if a relevant failure mode is not included in the analysis, this might lead to an important underestimation of the calculated risk. Different guidelines and tools (FERC, 2005; García-Kabbabe et al., 2010) provide guidance for the identification, description, and structuring of new failure modes whenever necessary.

The vulnerability of the dam infrastructure to failure can be affected by climate change. As the conditions of the damreservoir system deteriorate or as the climate factors worsen, an update of the failure modes considered may be required. In particular, new failure modes may arise or previous ones may become obsolete. For instance, in the context of geological hazards, studies have confirmed the influence of climate change on slope stability (Damiano and Mercogliano, 2013; Dehn et al., 2000). A slope failure event near a dam site could eventually entail a part of the terrain falling into the reservoir or impacting the dam, which could trigger an overtopping of the dam and eventually a dam failure.

A similar hazard arises in glacial and periglacial environments in which the increasing temperatures will likely cause a decrease in thickness and area of glaciers and progressive permafrost degradation. This thermal perturbation would entail stress redistributions and fast modification of the mechanical conditions at depth (Schneider et al., 2011), which could lead to rock-ice avalanches or glacial lake outburst floods (GLOFs) entering the reservoir (Evans and Delaney, 2015; Huggel et al., 2008; Stoffel and Huggel, 2012).

\subsubsection{Probability of failure}

Whether new failure modes are taken into account or not, the conditional probability of failure of the dam may also vary under new climatic conditions. To assess such probability and how it is impacted, one can disaggregate each failure mode into its failure mechanisms and then assess the probability of each of them by using different tools (e.g. reliability tools or expert judgment). The objective is to study whether, subject to the same loads, the dam responds differently under different conditions.

The potential variety of climate change effects is large but, for simplicity's sake, in this study only the typical failure modes are examined: overtopping, sliding, and internal erosion (piping). For instance, the structural behaviour of concrete dams, and especially arch dams, is directly influenced by temperature (Malm, 2016) and solar exposure (FERC, 1999). Under future climate change, average temperature is expected to increase in all climate scenarios and may have greater fluctuations during certain periods and reach more frequent extreme values (IPCC, 2013). Moreover, the potential variation in the water storage in the reservoir (see Sect. 3.1.2) can increase the exposition of the body of the dam to sun radiation (both in duration and surface), increasing the temperature difference and causing temperature peaks in the surface of the concrete. These factors can eventually expose the dam to additional mechanical stresses due to the temperature variations, thus making it more susceptible to hydrostatic loads. In these cases, conventional stability analyses may be not sufficient to assess whether the failure probabilities related to dam sliding are influenced by increasing temperatures and solar radiation and then should be adapted. It could thus be of help to perform mechanical and structural analyses, for instance using numerical tools such as finite element or finite difference methods. Similar studies can be applied in case other failure modes (e.g. overtopping or internal erosion) are found to be influenced by climate change.

In some cases, drier soil conditions are expected due to increasing temperatures and the precipitation pattern's variations. Moreover, as stated above, water pool levels may significantly vary and leave the dam at lower levels during long periods. This could reduce the soil moisture, thus changing the vulnerability of embankment dams to processes such as internal erosion. Indeed, moisture content (and even soil temperature) plays a key role in the internal erosion characteristics (Briaud, 2008). The decrease in water content decreases the critical shear stress and increases the coefficient of piping erosion, thus worsening the soil resistance against erosion (Wan and Fell, 2004). In addition, in dams with vegetated downstream faces, the loss of plants due to the change in soil moisture may on the one hand leave more or less deep holes that could make the soil more susceptible to internal erosion processes and on the other hand present less resistance to surface flow in the case of an overtopping event.

Whenever necessary, the assignation of failure probabilities should be complemented by expert consultancy and participatory workshops in which results from the models serve as relevant support for the understanding of the problem. More information about probability elicitation through expert judgment can be found in different guidelines (ANCOLD, 2003; Ayyub, 2001; SPANCOLD, 2012).

\subsection{Consequences}

Damage produced by a dam failure or an abnormal discharge release is in general very important, causing serious socioeconomic consequences. The analysis of these consequences is based on two parts: estimation of the outflow hydrographs and their routing downstream and calculation of the consequences.

\subsubsection{Outflow hydrographs}

An important aspect in the definition of the consequences is the routing of the non-failure and the failure outflow hydrographs. The first one results from the spills released by the outlet works and spillways during the flood routing; the latter one is due to the dam failure. Even if the outflow hydrograph originated by the dam break may be many times greater than in the non-failure case, the impact of climate change is considered analogous and can be analysed jointly. 
(a)

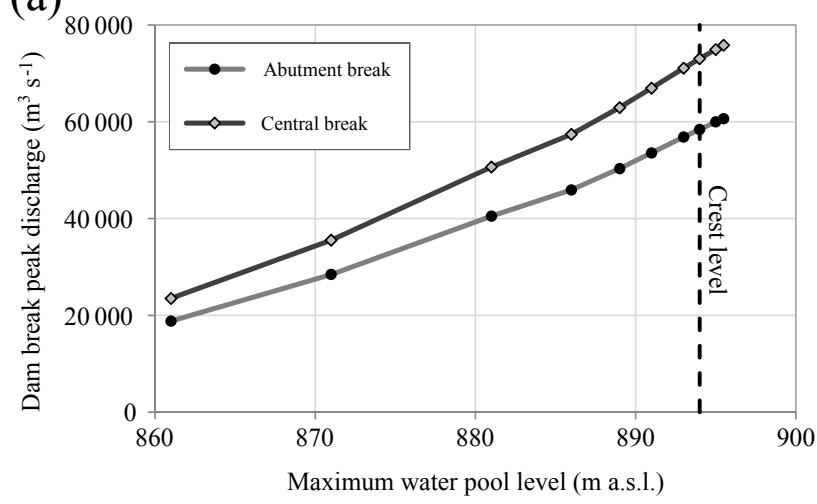

(b)

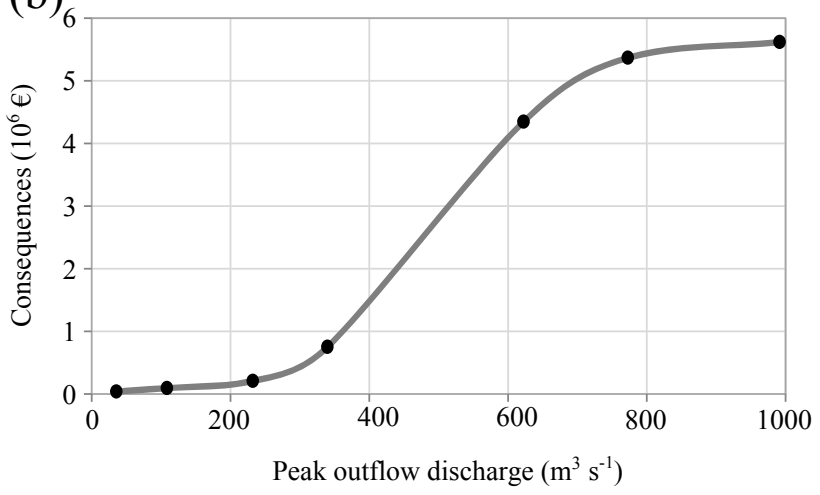

Figure 6. (a) Example of the relation between the maximum water level attained in the reservoir and failure peak discharge, depending on the failure mode considered (abutment or central break). (b) Example of discharge-consequences curve.

The study of downstream hydrographs can be split into two stages: estimation of the reservoir outflow hydrograph (through the dam breach or through the outlet works) and routing of the resulting hydrograph throughout the downstream inundation area.

On the one hand, the first stage can be characterized using curves that generally relate the maximum water level reached in the reservoir and the peak discharge (Fig. 6a). These relationships may include other variables depending on the specificities of each case: duration of the hydrograph, speed of the flood wave, etc. According to the hydraulic behaviour of the outflow hydrographs, there is no funded evidence that suggests relevant impacts of climate conditions on this aspect.

On the other hand, these outflow hydrographs are routed to estimate the resulting inundation maps downstream. This information is used to calculate the consequences curve in the case of peak discharge (Fig. 6b).

Land use changes can substantially affect the progression of the downstream inundation wave depending on the type of surface (e.g. urbanized or vegetation), its slope, etc. (Bornschein and Pohl, 2018; De Roo et al., 2001). Some studies have applied different techniques and models to forecast future land uses, which can be found in the literature (see Sect. 3.3.2). Furthermore, climatic factors such as temperature, precipitation, or carbon dioxide concentration are likely to influence plant growth (Morison and Morecroft, 2007; Peñuelas et al., 2004) with a high variability in time and space. This will not only induce a transformation of soil cover (upstream and downstream the dam) but will also affect the amount of sediment contained in the reservoir at the time of the flow release (Braud et al., 2001; Liu et al., 2014). In addition, some studies demonstrate that vegetation cover (Anderson et al., 2006; Järvelä, 2002) and incoming flood sediment concentration (Carrivick, 2010) may influence the propagation of downstream hydrographs. The flow resistance of vegetation increases the roughness of flood- plains and then attenuates wave celerity and dispersion of hydrographs while suspended sediment concentration changes fluid viscosity, thus affecting the acceleration and/or deceleration of the flow.

These two main factors - surface roughness and water viscosity - are typically used in floodplain models for the definition of inundation maps (Bladé et al., 2014; DHI, 2014; USACE, 2011a). By updating these inundation models with the projected values of the factors, it is possible to analyse their effect on the outflow hydrographs.

\subsubsection{Socio-economic consequences}

Once the downstream hydrographs are defined, it is possible to assess their consequences. A distinction can be made between the direct consequences - those created directly by the impact of the inundation wave - and the indirect consequences - induced by the direct impacts and which may occur outside the inundation event (Merz et al., 2004).

\section{Direct consequences}

On the one hand, the calculation of direct consequences due to inundations relies on two factors: exposure, which reflects the presence of people, livelihoods, infrastructure, or assets in an at-risk area, and vulnerability, which refers to their propensity to be adversely affected (Cardona et al., 2012; IPCC, 2012a). For the assessment of the impact on direct consequences, changes in exposure and vulnerability are analysed.

According to long-term disaster records, some studies have revealed an increase in the losses due to extreme weather events (Mechler and Kundzewicz, 2010; Peduzzi et al., 2009; Swiss Re, 2016; UNISDR, 2009). The long-term trends in these losses are attributed to the increasing exposure of people and economic assets in at-risk areas due to population and economic growth (Bouwer, 2011; Changnon et al., 2000; Miller et al., 2008; Pielke Jr. et al., 2005) rather 
than to climatic drivers (Choi and Fischer, 2003; Crompton and McAneney, 2008; Neumayer and Barthel, 2011). This can be extrapolated to inundations (Barredo, 2009; Hilker et al., 2009; Pielke Jr. and Downton, 2000) and hence to the dam risk framework. Indeed, potential increases in the socioeconomic losses are directly influenced by the enhancing presence of people and economic assets in at-risk areas due to population and economic growth (Handmer et al., 2012).

It is also expected that vulnerability to flooding events will be affected, especially when referring to population vulnerability in poor or underdeveloped environments. Indeed, the capacity to anticipate and respond to inundation risk depends on the existence of public education on risk, warning systems, or coordination between emergency agencies and authorities (Escuder-Bueno et al., 2012). In a changing world, these capacities may vary with socio-economic development. For example, a potential reduction of economic support for population training or for the maintenance of warning systems may entail a reduced capacity of response, thus increasing its vulnerability.

The assessment of the change in the exposure and vulnerability of the at-risk population and assets due to non-climatic drivers depends on the population and economic growth and should be based on socioeconomic development, urbanization, and infrastructure construction information. Few works have jointly studied both factors when assessing losses from climate change (Hall, 2003; Pielke Jr., 2007; Schmidt et al., 2009).

Regarding population growth, a simple approach could consider the past demographic evolution in the affected areas and extrapolate it to future scenarios. Another option is using existing projections at a regional or national scale such as those available in the online publication Our World in Data (2018), extracted from the UN database (United Nations, 2017). If no specific data are available and due to the complexity of proceeding otherwise, it can be considered that the same current assets and services at risk remain so in the future. Only the update of their economic value (cost) is to be applied. Bouwer et al. (2010) propose the application of a factor reflecting the estimate of the increase in value of the at-risk assets based on the index for annual change in gross domestic product (GDP). Results of long-term forecasts for the GDP for different countries (up to 2060) can be found in OECD (2018), which are based on an assessment of the economic climate in individual countries and the world economy.

More detailed projections (population, land use, and value of assets) can be achieved based on quantitative indicators of societal and economical changes and on the application of specific land use and population growth models. For instance, Maaskant et al. (2009) use projections and spatial distribution of population extracted from a land use model (Schotten et al., 2001) under a high economic growth scenario. Although this scenario was specifically developed for the Netherlands, useful indications can be obtained from other work or guides for the definition and application of socio-economic scenarios (Riahi et al., 2017; UK Climate Impacts Programme, 2000). These practices are often complex and seldom applied (Feyen et al., 2008). Indeed, results of the application of such scenarios are highly dependent on the chosen scenario(s) and must include the corresponding uncertainty. Moreover, land use and economic models can be based on individual behaviour and microeconomic trends that are difficult to capture.

Regarding changes in the population vulnerability, there are different methodologies to assess the inundation severity levels according to the socio-economic context. EscuderBueno et al. (2011) propose a classification to assess potential loss of life in urban areas in the case of river flooding depending on several factors. Once a socio-economic scenario has been chosen, it is possible (although not always easy) to study how these factors will evolve and then update the vulnerability accordingly.

\section{Indirect consequences}

On the other hand, climate change may influence indirect consequences. In particular, services and products related to water are of special importance in the context of climate change. Indeed, the value of water allocated to irrigation or hydropower production is likely to vary due to the expected alteration of the distribution, volume, and timing of water resources in the future (Fischer et al., 2007; Rodríguez Díaz et al., 2007; Solaun and Cerdá, 2017; U.S. Department of Energy, 2013). Dams are a key component when assessing socio-economic scenarios and their importance may even increase under future climatic conditions (more frequent droughts and extreme events, for instance). Thus, in the case of dam failure or serious malfunctioning, the absence of the structure would indeed induce some consequences caused by being unable to manage part of the water volume.

The assessment of how climate change may impact the indirect consequences is often very complex given the number of components involved and their interrelations. When a deep analysis may be impracticable, indirect costs can be estimated as a fix percentage of direct cost (James and Lee, 1970; SPANCOLD, 2012). This fix percentage could be simply applied to the direct costs that must be re-evaluated under the new climate change scenarios. When the application of a fixed percentage may lead to important errors (e.g. in the case of an airport, for which the indirect costs involved by the interruption of the aerial traffic are much more important than the direct ones), more detailed work is advised.

Deeper analyses require complex modelling of the economic system to assess how it would be affected by the impact of climate change. First, if it has not yet been carried out, an identification of the potentially affected services and economic activities is required (e.g. electric or telecommunications supply, industrial production). Then, specific mod- 
Table 2. Summary of climate change impacts on the different dam safety components and suggested methods for their assessment.

\begin{tabular}{|c|c|c|}
\hline Risk component & Climate change impacts & Assessment methods \\
\hline Flood & $\begin{array}{l}\text { Variations in local floods are expected due to changes in } \\
\text { - heavy rainfall patterns. } \\
\text { - snow cover and snowmelt processes. } \\
\text { - vegetation or soil moisture. }\end{array}$ & $\begin{array}{l}\text { - Direct application of previous analyses. } \\
\text { - Combination of climate projections, downscaling, and } \\
\text { hydro-meteorological modelling (Fig. 4). } \\
\text { - Uncertainties inherent in climate and hydrological } \\
\text { projections and changes in the watershed model. }\end{array}$ \\
\hline Reservoir water levels & $\begin{array}{l}\text { Fluctuations in water storage are due to } \\
\text { - precipitation variability, potential evapotranspiration, } \\
\text { or decreased snow and ice storage. } \\
\text { - changes and adaptations in land use and water de- } \\
\text { mand. }\end{array}$ & $\begin{array}{l}\text { - Combination of climate projections, downscaling } \\
\text { techniques, and simulation of the system of water re- } \\
\text { source management. } \\
\text { - Importance of non-climatic drivers (e.g. changes in } \\
\text { land use, adaptation of a reservoir's exploitation rules). }\end{array}$ \\
\hline Gate performance & $\begin{array}{l}\text { - Abrasion processes due to increases in the sediment } \\
\text { content of the water. } \\
\text { - Blockage of the gates due to suspended material. } \\
\text { - Changes in temperature causing stresses and deforma- } \\
\text { tions. }\end{array}$ & $\begin{array}{l}\text { - Qualitative assessment of the impacts of new climatic } \\
\text { conditions and stressors (Table 1). } \\
\text { - The use of fault trees. }\end{array}$ \\
\hline Flood routing strategy & $\begin{array}{l}\text { Operation rules are likely to adapt under certain cli- } \\
\text { mate conditions (e.g. changes in heavy rainfalls induc- } \\
\text { ing variations in the flood hydrographs' concentration } \\
\text { time). }\end{array}$ & Re-evaluation of the flood routing criteria. \\
\hline Failure modes & $\begin{array}{l}\text { New failure modes that may arise, in particular in the } \\
\text { context of glacier melt and slope stability or GLOF oc- } \\
\text { currence directly impacting the dam structure. }\end{array}$ & $\begin{array}{l}\text { Guidelines and tools to identify, describe, and structure } \\
\text { new failure modes or remove obsolete ones. }\end{array}$ \\
\hline Probability of failure & $\begin{array}{l}\text { - Temperature fluctuations may induce additional me- } \\
\text { chanical stresses in concrete dams. } \\
\text { - Drier soils and water level fluctuations can increase } \\
\text { processes such as internal erosion in embankment } \\
\text { dams. }\end{array}$ & $\begin{array}{l}\text { Probability can be elicited through expert judgment in } \\
\text { different guidelines. }\end{array}$ \\
\hline Outflow hydrographs & $\begin{array}{l}\text { The outflow hydrograph routing is affected by } \\
\text { - roughness of the surface. } \\
\text { - water viscosity related to flood sediment concentra- } \\
\text { tion. }\end{array}$ & $\begin{array}{l}\text { Inundation models can be used to assess the sensitivity } \\
\text { of the outflow hydrographs to these factors. }\end{array}$ \\
\hline Socio-economic consequences & $\begin{array}{l}\text { Direct consequences can be assessed through } \\
\text { - exposure changes due to population growth. } \\
\text { - update of the assets' economic value. } \\
\text { Indirect consequences include } \\
\text { - the value of water for irrigation or hydropower pro- } \\
\text { duction being likely to vary, which implies changes in } \\
\text { the cost of interruption of services and/or activities. }\end{array}$ & $\begin{array}{l}\text { Direct consequences can be assessed through } \\
\text { - application of demographic projections. } \\
\text { - detailed land use and population growth models based } \\
\text { on socio-economic scenarios. } \\
\text { - assessment of flood severity levels according to the } \\
\text { socio-economic context. } \\
\text { Indirect consequences can be assessed through } \\
\text { - estimation as a fixed percentage of direct costs. } \\
\text { - complex modelling of the economic system and as- } \\
\text { sessment of costs induced by the interruption of services } \\
\text { and/or activities. }\end{array}$ \\
\hline
\end{tabular}

els are to be used to assess the indirect costs induced by the interruption of these services and/or activities due to a dam failure or disruption event. Different methodologies, such as the input-output or the computable general equilibrium analyses (U.S. Department of Homeland Security, 2011), can be applied to study the variations in the economic flows after the flood. An analysis of how each component used in these models is susceptible to change in the future must be carried out.

In order to simplify the work, one can study only the impact in the most relevant activities affected (e.g. services and products related to water such as irrigation or hydropower production). Different works and methodologies have been developed to analyse how climate change may affect the resulting damage on the water resource systems (Hutton et al., 2007; Kazem et al., 2016; Quiroga et al., 2011).

\subsection{Summary}

A succinct summary of the main impacts identified for each dam risk component is presented in Table 2 along with some recommended techniques and methods for their assessment. 


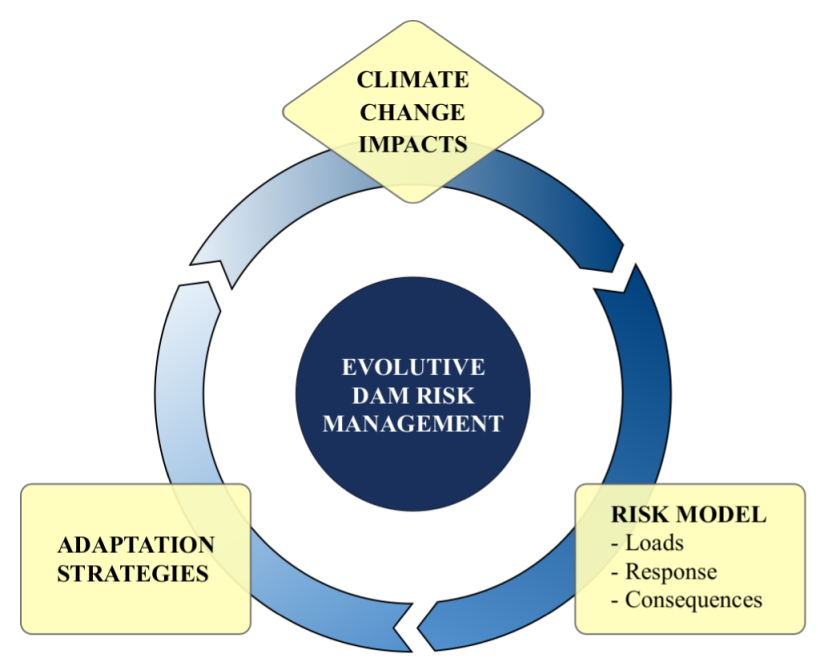

Figure 7. Evolutive dam risk management driven by climate change impacts on risk components, including adaptation strategies.

\section{Conclusions}

This work presents an interdisciplinary review of the state-ofthe-art research on projected climate change impacts on dam safety attending to both climatic and non-climatic drivers. The structure followed for such a review is based on the risk analysis approach in which all the variables concerning dam safety - from the hydrological loads to the consequences of failure - and their interdependencies are included in a comprehensive way. The extent of the analysis to be performed should depend on the detail level chosen. Paired with the impacts identified, the paper also presents useful techniques for their direct application to provide information for dam owners and dam safety practitioners in their decision-making process. Although the information collected in this work is mainly based on existing works, there is still some novelty or innovation in its processing since usually the global effects of climate change on dam risk are studied separately. The authors introduce a more comprehensive and structured approach to take them into account, which can be used to apply this same risk analysis to other critical infrastructures.

The purpose of this review is to serve as a dam safety management supporting tool to assess the vulnerability of the dam to climate change, i.e. the additional risk imposed by climate change effects, and to define adaptation strategies for new climate scenarios under an evolutive dam risk management framework (Fig. 7). Under this approach, dam risk models must be updated following the effects of climate change on each of the risk components, which will later help define the adaptation strategies to be followed. As climate projections evolve with new scenarios of models, the process must be replicated iteratively.

With this information, long-term investments can be planned more efficiently. Indeed, the application of such a tool may prevent investment in measures that would no longer be necessary in the future or missing some measures that could reduce the future risk. As such, it is addressed to dam owners and dam safety practitioners but also to the research community that can help improve it and fill the gaps that still remain in some aspects of the risk assessment.

The present work is based on available data sources and information at current levels of knowledge. However, this type of research is highly dynamic and advances in science and techniques for the assessment of these climate change effects are expected over time. Therefore, climate change impacts can then be iteratively actualized along with the forthcoming innovations and advances in science and techniques for the assessment of these effects. In particular, climate modellers as well as dam engineers face significant uncertainties when proposing and assessing climate scenarios and their impact on the different components involved in dam safety. The assignation of probabilities to uncertain future conditions and scenarios remains a major challenge and thus the management of dam safety based on climate change impacts must take into account these limitations.

Data availability. No data sets were used in this article.

Author contributions. JFS prepared the paper with contributions from all co-authors.

Competing interests. The authors declare that they have no conflict of interest.

Edited by: Bruno Merz

Reviewed by: two anonymous referees

\section{References}

Altarejos-García, L., Escuder-Bueno, I., Serrano-Lombillo, A., and de Membrillera-Ortuño, M.: Methodology for estimating the probability of failure by sliding in concrete gravity dams in the context of risk analysis, Struct. Saf., 36-37, 1-13, https://doi.org/10.1016/j.strusafe.2012.01.001, 2012.

ANCOLD: Guidelines on Risk Assessment, Tech. rep., Australian National Committee on Large Dams, 2003.

Anderson, B., Rutherfurd, I., and Western, A.: An analysis of the influence of riparian vegetation on the propagation of flood waves, Environ. Model. Softw., 21, 1290-1296, https://doi.org/10.1016/j.envsoft.2005.04.027, 2006.

Andreu, J., Capilla, J., and Sanchís, E.: AQUATOOL, a generalized decision-support system for water-resources planning and operational management, J. Hydrol., 177, 269-291, https://doi.org/10.1016/0022-1694(95)02963-X, 1996.

Ardiles, L., Sanz, D., Moreno, P., Jenaro, E., Fleitz, J., and EscuderBueno, I.: Risk Assessment and Management for 26 Dams Operated By the Duero River Authority (Spain), in: 6th International 
Conference on Dam Engineering, edited by: Pina, C., Portela, E., Gomes, J., Lisbon, Portugal, 15-17 February 2011.

Arheimer, B. and Lindström, G.: Climate impact on floods: changes in high flows in Sweden in the past and the future (1911-2100), Hydrol. Earth Syst. Sci., 19, 771-784, https://doi.org/10.5194/hess-19-771-2015, 2015.

Arnbjerg-Nielsen, K., Willems, P., Olsson, J., Beecham, S., Pathirana, A., Bülow Gregersen, I., Madsen, H., and Nguyen, V.T.-V.: Impacts of climate change on rainfall extremes and urban drainage systems: a review, Water Sci. Technol., 68, 16-28, https://doi.org/10.2166/wst.2013.251, 2013.

Atkins: Impact of Climate Change on Dams \& Reservoirs, Final Guidance Report FD2628, Department of Environment, Food and Rural Affairs, 2013.

Aven, T.: The risk concept-historical and recent development trends, Reliab. Eng. Syst. Safe., 99, 33-44, https://doi.org/10.1016/j.ress.2011.11.006, 2012.

Ayyub, B. M.: Elicitation of expert opinions for uncertainty and risks, CRC Press, Boca Raton, Florida, 2001.

Bahls, V. and Holman, K.: Climate Change in Hydrologic Hazard Analyses: Friant Dam Pilot Study - Part I: Hydrometeorological Model Inputs, Tech. rep., U.S. Department of the Interior, Bureau of Reclamation, 2014.

Barredo, J. I.: Normalised flood losses in Europe: 19702006, Nat. Hazards Earth Syst. Sci., 9, 97-104, https://doi.org/10.5194/nhess-9-97-2009, 2009.

Bates, B., Kundzewicz, Z., Wu, S., and Palutikof, J. (Eds.): Climate change and water, Technical Paper of the Intergovernmental Panel on Climate Change, Geneva, ipcc secretariat edn., 2008.

Bladé, E., Cea, L., Corestein, G., Escolano, E., Puertas, J., VázquezCendón, E., Dolz, J., and Coll, A.: Iber: herramienta de simulación numérica del flujo en ríos, Revista Internacional de Métodos Numéricos para Cálculo y Diseño en Ingeniería, 30, 1-10, https://doi.org/10.1016/j.rimni.2012.07.004, 2014.

Bornschein, A. and Pohl, R.: Land use influence on flood routing and retention from the viewpoint of hydromechanics: Land use influence on flood routing and retention, J. Flood Risk Manag., 11, 6-14, https://doi.org/10.1111/jfr3.12289, 2018.

Bouwer, L. M.: Have Disaster Losses Increased Due to Anthropogenic Climate Change?, B. Am. Meteorol. Soc., 92, 39-46, https://doi.org/10.1175/2010BAMS3092.1, 2011.

Bouwer, L. M., Bubeck, P., and Aerts, J. C.: Changes in future flood risk due to climate and development in a Dutch polder area, Global Environ. Change, 20, 463-471, https://doi.org/10.1016/j.gloenvcha.2010.04.002, 2010.

Bowles, D.: Advances in the practice and use of portfolio risk assessment, in: ANCOLD Conference on Dams, 2000.

Bowles, D., Brown, A., Hughes, A., Morris, M., Sayers, P., Topple, A., Wallis, M., and Gardiner, K.: Guide to risk assessment for reservoir safety management, Volume 1: Guide, Tech. Rep. SC090001/R1, Environment Agency, Horison House, Deanery Road, Bristol, BS1 9AH, 2013a.

Bowles, D., Brown, A., Hughes, A., Morris, M., Sayers, P., Topple, A., Wallis, M., and Gardiner, K.: Guide to risk assessment for reservoir safety management, Volume 2: Methodology and supporting information, Tech. Rep. SC090001/R2, Environment Agency, Horison House, Deanery Road, Bristol, BS1 9AH, $2013 b$.
Braud, I., Vich, A., Zuluaga, J., Fornero, L., and Pedrani, A.: Vegetation influence on runoff and sediment yield in the Andes region: observation and modelling, J. Hydrol., 254, 124-144, https://doi.org/10.1016/S0022-1694(01)00500-5, 2001.

Briaud, J.-L.: Case Histories in Soil and Rock Erosion: Woodrow Wilson Bridge, Brazos River Meander, Normandy Cliffs, and New Orleans Levees, J. Geotech. Geoenviron., 134, 1425-1447, https://doi.org/10.1061/(ASCE)10900241(2008)134:10(1425), 2008.

British Columbia, Water Management Branch, British Columbia, and Dam Safety Unit: Inspection \& maintenance of dams: dam safety guidelines, British Columbia, Water Management Branch, Victoria, 1998.

Cardona, O., van Aalst, M., Birkmann, J., Fordham, M., McGregor, G., Perez, R., Pulwarty, R., Schipper, E., and Sinh, B.: Determinants of risk: exposure and vulnerability, in: Managing the Risks of Extreme Events and Disasters to Advance Climate Change Adaptation, edited by: Field, C., Barros, V., Stocker, T., Qin, D., Dokken, D., Ebi, K., Mastrandrea, M., Mach, K., Plattner, G.K., Allen, S., Tignor, M., and Midgley, P., A Special Report of Working Groups I and II of the Intergovernmental Panel on Climate Change (IPCC), Cambridge University Press, Cambridge, UK, New York, NY, USA, 65-108, 2012.

Carrivick, J. L.: Dam break - Outburst flood propagation and transient hydraulics: A geosciences perspective, J. Hydrol., 380, 338-355, https://doi.org/10.1016/j.jhydrol.2009.11.009, 2010.

CH2014-Impacts: Toward quantitative scenarios of climate change impacts in Switzerland, OCCR, FOEN, MeteoSwiss, C2SM, Agroscope and ProClim, Bern, Switzerland, 2014.

Chaney, N. W., Herman, J. D., Reed, P. M., and Wood, E. F.: Flood and drought hydrologic monitoring: the role of model parameter uncertainty, Hydrol. Earth Syst. Sci., 19, 3239-3251, https://doi.org/10.5194/hess-19-3239-2015, 2015.

Changnon, S. A., Pielke, R. A., Changnon, D., Sylves, R. T., and Pulwarty, R.: Human Factors Explain the Increased Losses from Weather and Climate Extremes, B. Am. Meteorol. Soc., 81, 437-442, https://doi.org/10.1175/15200477(2000)081<0437:HFETIL>2.3.CO;2, 2000.

Chernet, H. H., Alfredsen, K., and Midttømme, G. H.: Safety of Hydropower Dams in a Changing Climate, J. Hydrol. Eng., 19, 569-582, https://doi.org/10.1061/(ASCE)HE.19435584.0000836, 2014.

Choi, O. and Fischer, A.: The Impacts of Socioeconomic Development and Climate Change on Severe Weather Catastrophe Losses: Mid-Atlantic Region (MAR) And the U.S., Clim. Change, 58, 149-170, https://doi.org/10.1023/A:1023459216609, 2003.

Commonwealth of Australia: National Climate Resilience and Adaptation Strategy, Tech. rep., 2015.

Crompton, R. P. and McAneney, K. J.: Normalised Australian insured losses from meteorological hazards: 1967-2006, Environ. Sci. Policy, 11, 371-378, https://doi.org/10.1016/j.envsci.2008.01.005, 2008.

Damiano, E. and Mercogliano, P.: Potential Effects of Climate Change on Slope Stability in Unsaturated Pyroclastic Soils, in: Landslide Science and Practice, edited by: Margottini, C., Canuti, P., and Sassa, K., Springer Berlin Heidelberg, Berlin, Heidelberg, 15-25, https://doi.org/10.1007/978-3-64231337-0_2, 2013. 
Dankers, R. and Feyen, L.: Climate change impact on flood hazard in Europe: An assessment based on high-resolution climate simulations, J. Geophys. Res., 113, D19105, https://doi.org/10.1029/2007JD009719, 2008.

De Roo, A., Odijk, M., Schmuck, G., Koster, E., and Lucieer, A.: Assessing the effects of land use changes on floods in the meuse and oder catchment, Phys. Chem. Earth Pt. B, 26, 593-599, https://doi.org/10.1016/S1464-1909(01)00054-5, 2001.

Dehn, M., Bürger, G., Buma, J., and Gasparetto, P.: Impact of climate change on slope stability using expanded downscaling, Eng. Geol., 55, 193-204, https://doi.org/10.1016/S00137952(99)00123-4, 2000.

DHI: MIKE FLOOD User Manual, Tech. rep., Danish Hydraulic Institute - Water and Environment, Hørsholm, Denmark, 2014.

Dixon, K. W., Lanzante, J. R., Nath, M. J., Hayhoe, K., Stoner, A., Radhakrishnan, A., Balaji, V., and Gaitán, C. F.: Evaluating the stationarity assumption in statistically downscaled climate projections: is past performance an indicator of future results?, Clim. Change, 135, 395-408, https://doi.org/10.1007/s10584016-1598-0, 2016.

Dobler, C., Bürger, G., and Stötter, J.: Simulating future precipitation extremes in a complex Alpine catchment, Nat. Hazards Earth Syst. Sci., 13, 263-277, https://doi.org/10.5194/nhess-13263-2013, 2013.

Duan, J. G., Bai, Y., Dominguez, F., Rivera, E., and Meixner, T.: Framework for incorporating climate change on flood magnitude and frequency analysis in the upper Santa Cruz River, J. Hydrol., 549, 194-207, https://doi.org/10.1016/j.jhydrol.2017.03.042, 2017.

Escuder-Bueno, I. and González-Pérez, J.: Metodología para la evaluación del riesgo hidrológico de presas y priorización de medidas correctoras, Colegio de Ingeniero de Caminos, Canales y Puertos, Madrid, Spain, 2014.

Escuder-Bueno, I., Castillo-Rodriguez, J., Perales-Momparler, S., and Morales-Torres, A.: SUFRI methodology for pluvial and river flooding risk assessment in urban areas to inform decision-making, SUFRI project, WP3, final report, Tech. rep., available at: http://www.edams.upv.es/docs/2011_July_SUFRI_ WP3_FinalReport.pdf (last access: 13 September 2018), 2011.

Escuder-Bueno, I., Castillo-Rodríguez, J. T., Zechner, S., Jöbstl, C., Perales-Momparler, S., and Petaccia, G.: A quantitative flood risk analysis methodology for urban areas with integration of social research data, Nat. Hazards Earth Syst. Sci., 12, 2843-2863, https://doi.org/10.5194/nhess-12-2843-2012, 2012.

European Commission: An EU Strategy on adaptation to climate change, available at: http://eur-lex.europa.eu/legal-content/EN/ TXT/PDF/?uri=CELEX:52009DC0147\&from=EN (last access: 13 September 2018), 2013.

Evans, S. G. and Delaney, K. B.: Catastrophic Mass Flows in the Mountain Glacial Environment, in: Snow and IceRelated Hazards, Risks and Disasters, Elsevier, 563-606, https://doi.org/10.1016/B978-0-12-394849-6.00016-0, 2015.

Fassnacht, S. R. and Records, R. M.: Large snowmelt versus rainfall events in the mountains: Big Mountain Snowmelt vs Rainfall Events, J. Geophys. Res.-Atmos., 120, 2375-2381, https://doi.org/10.1002/2014JD022753, 2015.

FEMA: Federal Guidelines for Dam Safety Risk Management, FEMA P-1025, Federal Emergency Management Agency, 2015.
FERC: Arch Dams, in: Engineering Guidelines for the Evaluation of Hydropower Projects, Federal Energy Regulatory Commission, Division of Dam Safety and Inspections, Washington, DC, 1999.

FERC: Engineering Guidelines for the Evaluation of Hydropower Projects, in: Dam Safety Performance Monitoring Program, Federal Energy Regulatory Commission, 2005.

Feyen, L., Barredo, J., and Dankers, R.: Implications of global warming and urban land use change on flooding in Europe, in: Water and Urban Development Paradigms: Towards an Integration of Engineering, Design and Management Approaches, CRC Press, Boca Raton, Florida, 217-225, 2008.

Fischer, G., Tubiello, F. N., van Velthuizen, H., and Wiberg, D. A.: Climate change impacts on irrigation water requirements: Effects of mitigation, 1990-2080, Technol. Forecast. Soc., 74, 10831107, https://doi.org/10.1016/j.techfore.2006.05.021, 2007.

García-Kabbabe, L., Chaparro-Carrasquel, L., Escuder-Bueno, I., and Serrano-Lombillo, A.: Metodología para estructurar modos de fallo en sistemas presa-embalse, Valladolid, Spain, 2010.

Gilroy, K. L. and McCuen, R. H.: A nonstationary flood frequency analysis method to adjust for future climate change and urbanization, J. Hydrol., 414-415, 40-48, https://doi.org/10.1016/j.jhydrol.2011.10.009, 2012.

Girón, F.: The evacuation of floods during the operation of reservoir, in: 16th ICOLD Congress, International Commission on large dams (ICOLD), San Francisco, USA, 1988.

Hall, J.: Quantified scenarios analysis of drivers and impacts of changing flood risk in England and Wales: 2030-2100, Global Environ. Change, 5, 51-65, https://doi.org/10.1016/j.hazards.2004.04.002, 2003.

Handmer, J., Honda, Y., Kundzewicz, Z., Arnell, N., Benito, G., Hatfield, J., Mohamed, I., Peduzzi, P., Wu, S., Sherstyukov, B., Takahashi, K., and Yan, Z.: Changes in impacts of climate extremes: human systems and ecosystems, in: Managing the Risks of Extreme Events and Disasters to Advance Climate Change Adaptation, edited by: Field, C., Barros, V., Stocker, T., Qin, D., Dokken, D., Ebi, K., Mastrandrea, M., Mach, K., Plattner, G.K., Allen, S., Tignor, M., and Midgley, P., A Special Report of Working Groups I and II of the Intergovernmental Panel on Climate Change (IPCC), Cambridge University Press, Cambridge, UK, New York, NY, USA, 231-290, 2012.

Hannaford, J. and Marsh, T. J.: High-flow and flood trends in a network of undisturbed catchments in the UK, Int. J. Climatol., 28, 1325-1338, https://doi.org/10.1002/joc.1643, 2008.

Hilker, N., Badoux, A., and Hegg, C.: The Swiss flood and landslide damage database 1972-2007, Nat. Hazards Earth Syst. Sci., 9, 913-925, https://doi.org/10.5194/nhess-9-913-2009, 2009.

Hirabayashi, Y., Mahendran, R., Koirala, S., Konoshima, L., Yamazaki, D., Watanabe, S., Kim, H., and Kanae, S.: Global flood risk under climate change, Nat. Clim. Change, 3, 816-821, https://doi.org/10.1038/nclimate1911, 2013.

Huggel, C., Caplan-Auerbach, J., and Wessels, R.: Recent Extreme Avalanches: Triggered by Climate Change?, Eos T. Am. Geophys. Un., 89, 469-470, https://doi.org/10.1029/2008EO470001, 2008.

Huss, M.: Present and future contribution of glacier storage change to runoff from macroscale drainage basins in Europe, Water Resour. Res., 47, W07511, https://doi.org/10.1029/2010WR010299, 2011. 
Huss, M., Jouvet, G., Farinotti, D., and Bauder, A.: Future high-mountain hydrology: a new parameterization of glacier retreat, Hydrol. Earth Syst. Sci., 14, 815-829, https://doi.org/10.5194/hess-14-815-2010, 2010.

Hutton, G., Haller, L., and Bartram, J.: Global cost-benefit analysis of water supply and sanitation interventions, J. Water Health, 5, 481-502, https://doi.org/10.2166/wh.2007.009, 2007.

ICOLD: Bulletin on risk assessment in dam safety management, Tech. rep., International Commission on Large Dams, 2003.

ICOLD: Risk assessment in dam safety management, A reconnaissance of benefits, methods and current applications, Bulletin 130, International Commission on Large Dams, 2005.

IPCC: Glossary of terms, in: Managing the Risks of Extreme Events and Disasters to Advance Climate Change Adaptation, edited by: Field, C., Barros, V., Stocker, T., Qin, D., Dokken, D., Ebi, K., Mastrandrea, M., Mach, K., Plattner, G.-K., Allen, S., Tignor, M., and Midgley, P., A Special Report of Working Groups I and II of the Intergovernmental Panel on Climate Change (IPCC), Cambridge University Press, Cambridge, UK, New York, NY, USA, 555-564, 2012a.

IPCC: Managing the risks of extreme events and disasters to advance climate change adaptation: special report of the Intergovernmental Panel on Climate Change, Cambridge Univ. Press, Cambridge, UK, New York, NY, USA, 1st publ. edn., 2012b.

IPCC: Climate Change 2013: The Physical Science Basis, Contribution of Working Group I to the Fifth Assessment Report of the Intergovernmental Panel on Climate Change, Cambridge University Press, Cambridge, UK, New York, NY, USA, 2013.

IPCC: Climate Change 2014: Impacts, Adaptation, and Vulnerability, Part A: Global and Sectoral Aspects, Contribution of Working Group II to the Fifth Assessment Report of the Intergovernmental Panel on Climate Change, Cambridge Univ. Press, Cambridge, UK, New York, NY, USA, 2014.

James, L. and Lee, R.: Economics of water resources planning, McGraw-Hill series in water resources and environmental engineering, McGraw-Hill Book Co., 615 pp., 1970.

Järvelä, J.: Flow resistance of flexible and stiff vegetation: a flume study with natural plants, J. Hydrol., 269, 44-54, https://doi.org/10.1016/S0022-1694(02)00193-2, 2002.

Kaplan, S.: The Words of Risk Analysis, Risk Anal., 17, 407-417, https://doi.org/10.1111/j.1539-6924.1997.tb00881.x, 1997.

Kaplan, S. and Garrick, B. J.: On The Quantitative Definition of Risk, Risk Anal., 1, 11-27, https://doi.org/10.1111/j.15396924.1981.tb01350.x, 1981.

Kay, A. L., Reynard, N. S., and Jones, R. G.: RCM rainfall for UK flood frequency estimation. I. Method and validation, J. Hydrol., 318, 151-162, https://doi.org/10.1016/j.jhydrol.2005.06.012, 2006.

Kazem, M., McPhee, D., Torkaman Rashid, A., and Kazem, A.: Climate change and economic approaches into water allocation: optimization via direct benefits of water - the case study of Rudbar Lorestan hydropower dam (Iran), Sustain. Water Resour. Manage., 2, 461-472, https://doi.org/10.1007/s40899-016-00672, 2016.

Khaliq, M., Ouarda, T., Ondo, J.-C., Gachon, P., and Bobée, B.: Frequency analysis of a sequence of dependent and/or non-stationary hydro-meteorological observations: A review, J. Hydrol., 329, 534-552, https://doi.org/10.1016/j.jhydrol.2006.03.004, 2006.
Khazaei, M. R., Zahabiyoun, B., and Saghafian, B.: Assessment of climate change impact on floods using weather generator and continuous rainfall-runoff model, Int. J. Climatol., 32, 19972006, https://doi.org/10.1002/joc.2416, 2012.

Kingston, D. G., Todd, M. C., Taylor, R. G., Thompson, J. R., and Arnell, N. W.: Uncertainty in the estimation of potential evapotranspiration under climate change, Geophys. Res. Lett., 36, L20403, https://doi.org/10.1029/2009GL040267, 2009.

Kjeldsen, T., Macdonald, N., Lang, M., Mediero, L., Albuquerque, T., Bogdanowicz, E., Brázdil, R., Castellarin, A., David, V., Fleig, A., Gül, G., Kriauciuniene, J., Kohnová, S., Merz, B., Nicholson, O., Roald, L., Salinas, J., Sarauskiene, D., Šraj, M., Strupczewski, W., Szolgay, J., Toumazis, A., Vanneuville, W., Veijalainen, N., and Wilson, D.: Documentary evidence of past floods in Europe and their utility in flood frequency estimation, J. Hydrol., 517, 963-973, https://doi.org/10.1016/j.jhydrol.2014.06.038, 2014.

Klipsch, J. and Hurst, M.: HEC-ResSim Reservoir System Simulation User's Manual, Tech. rep., USACE, Institute for Water Resources, Hydrologic Engineering Center, Davis, CA, 2007.

Knutti, R., Furrer, R., Tebaldi, C., Cermak, J., and Meehl, G. A.: Challenges in Combining Projections from Multiple Climate Models, J. Climate, 23, 2739-2758, https://doi.org/10.1175/2009JCLI3361.1, 2010.

Kondolf, G. M., Gao, Y., Annandale, G. W., Morris, G. L., Jiang, E., Zhang, J., Cao, Y., Carling, P., Fu, K., Guo, Q., Hotchkiss, R., Peteuil, C., Sumi, T., Wang, H.-W., Wang, Z., Wei, Z., Wu, B., Wu, C., and Yang, C. T.: Sustainable sediment management in reservoirs and regulated rivers: Experiences from five continents, Earth's Future, 2, 256-280, https://doi.org/10.1002/2013EF000184, 2014.

Kundzewicz, Z., Mata, L., Arnell, N., Doll, P., Kabat, P., Jimenez, B., Miller, K., Oki, T., Sen, Z., and Shiklomanov, I.: Freshwater resources and their management, in: Climate Change 2007, Impacts, Adaptation and Vulnerability. Contribution of Working Group II to the Fourth Assessment Report of the Intergovernmental Panel on Climate Change, edited by: Parry, M., Canziani, O., Palutikof, J., Van Der Linde, P., and Hanson, C., Cambridge, UK, Cambridge University Press edition, 173-210, 2007.

Lanzante, J. R., Dixon, K. W., Nath, M. J., Whitlock, C. E., and Adams-Smith, D.: Some Pitfalls in Statistical Downscaling of Future Climate, B. Am. Meteorol. Soc., 99, 791-803, https://doi.org/10.1175/BAMS-D-17-0046.1, 2018.

Lawrence, D., Paquet, E., Gailhard, J., and Fleig, A. K.: Stochastic semi-continuous simulation for extreme flood estimation in catchments with combined rainfall-snowmelt flood regimes, Nat. Hazards Earth Syst. Sci., 14, 1283-1298, https://doi.org/10.5194/nhess-14-1283-2014, 2014.

Lewin, J., Ballard, G., and Bowles, D.: Spillway gate reliability in the context of overall dam failure risk, in: USSD Annual Lecture, Charleston, South Carolina, 2003.

Liu, Y.-J., Wang, T.-W., Cai, C.-F., Li, Z.-X., and Cheng, D.-B.: Effects of vegetation on runoff generation, sediment yield and soil shear strength on road-side slopes under a simulation rainfall test in the Three Gorges Reservoir Area, China, Sci. Total Environ., 485-486, 93-102, https://doi.org/10.1016/j.scitotenv.2014.03.053, 2014.

López, J. and Francés, F.: Non-stationary flood frequency analysis in continental Spanish rivers, using climate and reservoir indices 
as external covariates, Hydrol. Earth Syst. Sci., 17, 3189-3203, https://doi.org/10.5194/hess-17-3189-2013, 2013.

Maaskant, B., Jonkman, S. N., and Bouwer, L. M.: Future risk of flooding: an analysis of changes in potential loss of life in South Holland (The Netherlands), Environ. Sci. Policy, 12, 157-169, https://doi.org/10.1016/j.envsci.2008.11.004, 2009.

Malm, R.: Guidelines for FE Analyses of Concrete Dams, Tech. rep., ENERGIFORSK, 2016.

Mechler, R. and Kundzewicz, Z. W.: Assessing adaptation to extreme weather events in Europe-Editorial, Mitig. Adapt. Strat. Gl., 15, 611-620, https://doi.org/10.1007/s11027-010-9245-y, 2010.

Merz, B., Kreibich, H., Thieken, A., and Schmidtke, R.: Estimation uncertainty of direct monetary flood damage to buildings, Nat. Hazards Earth Syst. Sci., 4, 153-163, https://doi.org/10.5194/nhess-4-153-2004, 2004.

Merz, B., Hall, J., Disse, M., and Schumann, A.: Fluvial flood risk management in a changing world, Nat. Hazards Earth Syst. Sci., 10, 509-527, https://doi.org/10.5194/nhess-10-509-2010, 2010.

Miller, S., Muir-Wood, R., and Boisonnade, A.: An exploration of trends in normalised weather-related catastrophe losses, in: Climate Extremes and Society, edited by: Diaz, H. and Murnane, R., Cambridge University Press, Cambridge, UK, 225-247, 2008.

Morison, J. I. L. and Morecroft, M. D. (Eds.): Plant growth and climate change, Biological sciences series, Blackwell Publishing, Oxford, 232 pp., 2007.

Mostbauer, K., Kaitna, R., Prenner, D., and Hrachowitz, M.: The temporally varying roles of rainfall, snowmelt and soil moisture for debris flow initiation in a snow-dominated system, Hydrol. Earth Syst. Sci., 22, 3493-3513, https://doi.org/10.5194/hess-223493-2018, 2018.

National Research Council: Informing decisions in a changing climate, National Academies Press, Washington, DC, https://doi.org/10.17226/12626, 2009.

Neumayer, E. and Barthel, F.: Normalizing economic loss from natural disasters: A global analysis, Global Environ. Change, 21, 13-24, https://doi.org/10.1016/j.gloenvcha.2010.10.004, 2011.

Novembre, N., Holman, K., and Bahls, V.: Climate Change in Hydrologic Hazard Analyses: Friant Dam Pilot Study - Part II: Using the SEFM with Climate-Adjusted Hydrometeorological Inputs, Technical Memorandum 8250-2015-010, U.S. Department of the Interior, Bureau of Reclamation, 2015.

OECC: Plan Nacional de Adaptación al Cambio Climático, Tech. rep., Oficina Española de Cambio Climático, Ministerio de Agricultura y Pesca, Alimentación y Medio Ambiente, available at: https://www.mapama.gob.es/es/cambio-climatico/temas/ impactos-vulnerabilidad-y-adaptacion/pna_v3_tcm7-12445_ tcm30-70393.pdf (last access: 13 September 2018), 2008.

OECD: GDP long-term forecast (indicator), available at: https://data.oecd.org/gdp/gdp-long-term-forecast.htm (last access: 13 September 2018), 2018.

OFEV (Ed.): Adaptation aux changements climatiques en Suisse, Plan d'action 2014-2019, Deuxième volet de la stratégie du Conseil fédéral du 9 avril 2014, Bern, Switzerland, 2014.

Our World in Data: Future Population Growth, available at: https://ourworldindata.org/future-population-growth (last access: 13 September 2018), 2018.

Paxson, G., McCann, M., and Landis, M.: A Risk Based Framework for Evaluating Gated Spillway Operations, in: 6th International Symposium on Hydraulic Structures, USU Libraries, Portland, Oregon, USA, 630-640, https://doi.org/10.15142/T3730628160853, 2016.

Peduzzi, P., Dao, H., Herold, C., and Mouton, F.: Assessing global exposure and vulnerability towards natural hazards: the Disaster Risk Index, Nat. Hazards Earth Syst. Sci., 9, 1149-1159, https://doi.org/10.5194/nhess-9-1149-2009, 2009.

Pereira-Cardenal, S. J., Madsen, H., Arnbjerg-Nielsen, K., Riegels, N., Jensen, R., Mo, B., Wangensteen, I., and Bauer-Gottwein, P.: Assessing climate change impacts on the Iberian power system using a coupled water-power model, Clim. Change, 126, 351364, https://doi.org/10.1007/s10584-014-1221-1, 2014.

Petrow, T. and Merz, B.: Trends in flood magnitude, frequency and seasonality in Germany in the period 1951-2002, J. Hydrol., 371, 129-141, https://doi.org/10.1016/j.jhydrol.2009.03.024, 2009.

Peñuelas, J., Gordon, C., Llorens, L., Nielsen, T., Tietema, A., Beier, C., Bruna, P., Emmett, B., Estiarte, M., and Gorissen, A.: Nonintrusive Field Experiments Show Different Plant Responses to Warming and Drought Among Sites, Seasons, and Species in a North-South European Gradient, Ecosystems, 7, 598-612, https://doi.org/10.1007/s10021-004-0179-7, 2004.

Pielke Jr., R. A.: Future economic damage from tropical cyclones: sensitivities to societal and climate changes, Philos. T. Roy. Soc. A, 365, 2717-2729, https://doi.org/10.1098/rsta.2007.2086, 2007.

Pielke Jr., R. A. and Downton, M. W.: Precipitation and Damaging Floods: Trends in the United States, 193297, J. Climate, 13, 3625-3637, https://doi.org/10.1175/15200442(2000)013<3625:PADFTI>2.0.CO;2, 2000.

Pielke Jr., R. A., Agrawala, S., Bouwer, L. M., Burton, I., Changnon, S., Glantz, M. H., Hooke, W. H., Klein, R. J. T., Kunkel, K., Mileti, D., Sarewitz, D., Thompkins, E. L., Stehr, N., and von Storch, H.: Clarifying the Attribution of Recent Disaster Losses: A Response to Epstein and McCarthy, B. Am. Meteorol. Soc., 86, 1481-1483, https://doi.org/10.1175/BAMS-86-101481, 2005.

Prudhomme, C. and Davies, H.: Assessing uncertainties in climate change impact analyses on the river flow regimes in the UK. Part 2: future climate, Clim. Change, 93, 197-222, https://doi.org/10.1007/s10584-008-9461-6, 2009.

Quiroga, S., Garrote, L., Iglesias, A., Fernández-Haddad, Z., Schlickenrieder, J., de Lama, B., Mosso, C., and SánchezArcilla, A.: The economic value of drought information for water management under climate change: a case study in the Ebro basin, Nat. Hazards Earth Syst. Sci., 11, 643-657, https://doi.org/10.5194/nhess-11-643-2011, 2011.

Raff, D. A., Pruitt, T., and Brekke, L. D.: A framework for assessing flood frequency based on climate projection information, Hydrol Earth Syst. Sci., 13, 2119-2136, https://doi.org/10.5194/hess-132119-2009, 2009.

Requena, A. I., Mediero, L., and Garrote, L.: A bivariate return period based on copulas for hydrologic dam design: accounting for reservoir routing in risk estimation, Hydrol. Earth Syst. Sci., 17 3023-3038, https://doi.org/10.5194/hess-17-3023-2013, 2013.

Riahi, K., van Vuuren, D. P., Kriegler, E., Edmonds, J., O’Neill, B. C., Fujimori, S., Bauer, N., Calvin, K., Dellink, R., Fricko, O., Lutz, W., Popp, A., Cuaresma, J. C., Kc, S., Leimbach, M. Jiang, L., Kram, T., Rao, S., Emmerling, J., Ebi, K., Hasegawa, T., Havlik, P., Humpenöder, F., Da Silva, L. A., Smith, S., Ste- 
hfest, E., Bosetti, V., Eom, J., Gernaat, D., Masui, T., Rogelj, J., Strefler, J., Drouet, L., Krey, V., Luderer, G., Harmsen, M., Takahashi, K., Baumstark, L., Doelman, J. C., Kainuma, M., Klimont, Z., Marangoni, G., Lotze-Campen, H., Obersteiner, M., Tabeau, A., and Tavoni, M.: The Shared Socioeconomic Pathways and their energy, land use, and greenhouse gas emissions implications: An overview, Global Environ. Change, 42, 153168, https://doi.org/10.1016/j.gloenvcha.2016.05.009, 2017.

Rodríguez Díaz, J. A., Weatherhead, E. K., Knox, J. W., and Camacho, E.: Climate change impacts on irrigation water requirements in the Guadalquivir river basin in Spain, Reg. Environ. Change, 7, 149-159, https://doi.org/10.1007/s10113-007-0035-3, 2007.

Sarr, M., Seidou, O., Tramblay, Y., and El Adlouni, S.: Comparison of downscaling methods for mean and extreme precipitation in Senegal, J. Hydrol., 4, 369-385, https://doi.org/10.1016/j.ejrh.2015.06.005, 2015.

Schmidt, S., Kemfert, C., and Faust, E.: Simulation of Economic Losses from Tropical Cyclones in the Years 2015 and 2050: The Effects of Anthropogenic Climate Change and Growing Wealth, Discussion paper 914, German Institute for Economic Research, Berlin, Germany, 2009.

Schneider, D., Huggel, C., Haeberli, W., and Kaitna, R.: Unraveling driving factors for large rock-ice avalanche mobility: UNRAVELING DRIVING FACTORS FOR LARGE ROCK-ICE AVALANCHE MOBILITY, Earth Surf. Proc. Land., 36, 19481966, https://doi.org/10.1002/esp.2218, 2011.

Schotten, K., Goetgeluk, R., Hilferink, M., Rietveld, P., and Scholten, H.: Residential Construction, Land Use and the Environment. Simulations for the Netherlands Using a GISBased Land Use Model, Environ. Model. Assess., 6, 133-143, https://doi.org/10.1023/A:1011531120436, 2001.

Seneviratne, S. I., Corti, T., Davin, E. L., Hirschi, M., Jaeger, E. B., Lehner, I., Orlowsky, B., and Teuling, A. J.: Investigating soil moisture-climate interactions in a changing climate: A review, Earth-Sci. Rev., 99, 125-161, https://doi.org/10.1016/j.earscirev.2010.02.004, 2010.

Serinaldi, F. and Grimaldi, S.: Fully Nested 3-Copula: Procedure and Application on Hydrological Data, J. Hydrol. Eng., 12, 420-430, https://doi.org/10.1061/(ASCE)10840699(2007)12:4(420), 2007.

Serrano-Lombillo, A., Escuder-Bueno, I., de Membrillera-Ortuño, M. G., and Altarejos-García, L.: Methodology for the Calculation of Annualized Incremental Risks in Systems of Dams: Risk Calculation for Systems of Dams, Risk Anal., 31, 1000-1015, https://doi.org/10.1111/j.1539-6924.2010.01547.x, 2011.

Serrano-Lombillo, A., Escuder-Bueno, I., and Altarejos-García, L.: Use of risk models for evaluation of risk reduction measures for dams, Commission Internationale des Grands Barrages, Kyoto, 2012.

Serrano-Lombillo, A., Morales-Torres, A., Escuder-Bueno, I., and Altarejos-García, L.: Review, Analysis and Application of Existing Risk Reduction Principles and Risk Indicators for Dam Safety Management, 2013.

Shamir, E., Megdal, S. B., Carrillo, C., Castro, C. L., Chang, H.-I., Chief, K., Corkhill, F. E., Eden, S., Georgakakos, K. P., Nelson, K. M., and Prietto, J.: Climate change and water resources management in the Upper Santa Cruz River, Arizona, J. Hydrol., 521, 18-33, https://doi.org/10.1016/j.jhydrol.2014.11.062, 2015.
Solaun, K. and Cerdá, E.: The Impact of Climate Change on the Generation of Hydroelectric Power-A Case Study in Southern Spain, Energies, 10, 1343, https://doi.org/10.3390/en10091343, 2017.

SPANCOLD: Risk Analysis as Applied to Dam Safety, Technical Guide on Operation of Dams and Reservoirs, Professional Association of Civil Engineers, Spanish National Committe on Large Dams, Madrid, available at: http://www. spancold.es/Archivos/Monograph_Risk_Analysis.pdf (last access: 13 September 2018), 2012.

Šraj, M., Viglione, A., Parajka, J., and Blöschl, G.: The influence of non-stationarity in extreme hydrological events on flood frequency estimation, J. Hydrol. Hydromech., 64, 426-437, https://doi.org/10.1515/johh-2016-0032, 2016.

Stamatelatos, M., Vesely, W., Dugan, J., Fragola, J., Minarick, J., and Railsback, J.: Fault tree handbook with aerospace applications, Tech. rep., NASA Office of Safety and Mission Assurance, 2002.

Stoffel, M. and Huggel, C.: Effects of climate change on mass movements in mountain environments, Prog. Phys. Geog., 36, 421-439, https://doi.org/10.1177/0309133312441010, 2012.

Sunyer, M., Madsen, H., and Ang, P.: A comparison of different regional climate models and statistical downscaling methods for extreme rainfall estimation under climate change, Atmos. Res., 103, 119-128, https://doi.org/10.1016/j.atmosres.2011.06.011, 2012.

Swiss Re: Natural catastrophes and man-made disasters in 2015: Asia suffers substantial losses, Tech. Rep. 1/2016, Swiss Reinsurance Company, Zurich, Switzerland, 2016.

Taye, M. T., Ntegeka, V., Ogiramoi, N. P., and Willems, P.: Assessment of climate change impact on hydrological extremes in two source regions of the Nile River Basin, Hydrol. Earth Syst. Sci., 15, 209-222, https://doi.org/10.5194/hess-15-209-2011, 2011.

UK Climate Impacts Programme: Socio-economic scenarios for climate change impact assessment: a guide to their use in the UK Climate Impacts Programme, Tech. rep., UKCIP, Oxford, 2000.

UNISDR: Global Assessment Report on Disaster Risk Reduction, United Nations International Strategy for Disaster Reduction Secretariat, Geneva, Switzerland, green ink, UK edition, 2009.

United Nations: World Population Prospects: The 2017 Revision, Tech. rep., Department of Economic and Social Affairs, Population Division, available at: https://esa.un.org/unpd/ wpp/Download/Standard/Population/ (last access: 13 September 2018), 2017.

U.S. Department of Energy: Effects of Climate Change on Federal Hydropower, Tech. Rep. 20585, Washington, DC, 2013.

U.S. Department of Homeland Security: Dam Sector, Estimating Economic Consequences for Dam Failure Scenarios, Tech. rep., 2011.

U.S. Government Accountability Office: Climate Change, Federal Efforts Under Way to Assess Water Infrastructure Vulnerabilities and Address Adaptation Challenges, Tech. Rep. GAO-14-23, 2013.

USACE: HEC-GeoRAS, GIS Tools for Support of HEC-RAS using ArcGIS, User's Manual, United States Army Corps of Engineers, Computer Program Documentation, Davis, CA, 2011a.

USACE: Safety of dams - Policy and procedures, Tech. Rep. ER 1110-2- 1156, United States Army Corps of Engineers, Washington, DC, 2011b. 
USACE: Climate Change Adaptation Plan, Tech. rep., United States Army Corps of Engineers, Committee on Climate Preparedness and Resilience, 2014.

USACE: Guidance for Incorporating Climate Change Impacts to Inland Hydrology in Civil Works Studies, Designs, and Projects, United States Army Corps of Engineers, EBC 2016-25, 2016.

USBR: Hydrology, hydraulics, and sediment studies for the Matilija Dam Ecosystem Restoration Project,United States Bureau of Reclamation, Ventura, CA - DRAFT Report, Tech. rep., Denver, CO, 2006.

USBR: Climate Change Adaptation Strategy, Tech. rep., U.S. Department of the Interior, United States Bureau of Reclamation, 2014.

USBR: Climate Change Adaptation Strategy: 2016 Progress Report, Tech. rep., U.S. Department of the Interior, United States Bureau of Reclamation, 2016.

Villarini, G., Serinaldi, F., Smith, J. A., and Krajewski, W. F.: On the stationarity of annual flood peaks in the continental United States during the 20th century, Water Resour. Res., 45, W08417, https://doi.org/10.1029/2008WR007645, 2009.

Walsh, J., Wuebbles, D., Hayhoe, K., Kossin, J., Kunkel, K., Stephens, G., Thorne, P., Vose, R., Wehner, M., Willis, J., Anderson, D., Doney, S., Feely, R., Hennon, P., Kharin, V., Knutson, T., Landerer, F., Lenton, T., Kennedy, J., and Somerville, R.: Our Changing Climate, chap. 2, in: Climate Change Impacts in the United States: The Third National Climate Assessment, edited by: Melillo, J. M., Richmond, T., and Yohe, G. W., U.S. Global Change Research Program, 19-67, https://doi.org/10.7930/J0KW5CXT, 2014.

Wan, C. F. and Fell, R.: Investigation of Rate of Erosion of Soils in Embankment Dams, J. Geotech. Geoenviron., 130, 373-380, https://doi.org/10.1061/(ASCE)10900241(2004)130:4(373), 2004.

Wilks, D. S.: Use of stochastic weathergenerators for precipitation downscaling: Use of stochastic precipitation generators, WIRES Clim. Change, 1, 898-907, https://doi.org/10.1002/wcc.85, 2010.
Willems, P. (Ed.): Impacts of climate change on rainfall extremes and urban drainage systems, IWA Publishing, London, ISBN: 9781780401256, 2012.

Willems, P.: Revision of urban drainage design rules after assessment of climate change impacts on precipitation extremes at Uccle, Belgium, J. Hydrol., 496, 166-177, https://doi.org/10.1016/j.jhydrol.2013.05.037, 2013.

Wobus, C., Gutmann, E., Jones, R., Rissing, M., Mizukami, N., Lorie, M., Mahoney, H., Wood, A. W., Mills, D., and Martinich, J.: Climate change impacts on flood risk and asset damages within mapped 100-year floodplains of the contiguous United States, Nat. Hazards Earth Syst. Sci., 17, 2199-2211, https://doi.org/10.5194/nhess-17-2199-2017, 2017.

World Meteorological Organization: Guide to hydrological practices, vol. II: Management of Water Resources and Application of Hydrological Practices, World Meteorological Organization, Geneva, 2008.

Yang, D., Kanae, S., Oki, T., Koike, T., and Musiake, K.: Global potential soil erosion with reference to land use and climate changes, Hydrol. Process., 17, 2913-2928, https://doi.org/10.1002/hyp.1441, 2003.

Zhang, L. and Singh, V. P.: Bivariate Flood Frequency Analysis Using the Copula Method, J. Hydrol. Eng., 11, 150-164, https://doi.org/10.1061/(ASCE)1084-0699(2006)11:2(150), 2006.

Zhang, Q., Gu, X., Singh, V. P., Xiao, M., and Chen, X.: Evaluation of flood frequency under non-stationarity resulting from climate indices and reservoir indices in the East River basin, China, J. Hydrol., 527, 565-575, https://doi.org/10.1016/j.jhydrol.2015.05.029, 2015. 